\title{
An overview of the potential environmental impacts of large-scale microalgae cultivation
}

\begin{abstract}
Philippa K. Usher', Andrew B. Ross* ${ }^{* 1}$, Miller Alonso Camargo-Valero" ${ }^{2,3}$, Alison S. Tomlin' \& William F. Gale'

Cultivation of microalgae for applications such as fuel, food, pharmaceuticals and farming is a rapidly developing area of research and investment. Whilst microalgae promises to deliver many environmental benefits compared with existing biofuel technology, there are also issues to overcome in relation to wastewater management, emissions control, land use change and responsible development of genetically modified organisms. This review seeks to highlight both the positive and negative impacts of microalgae cultivation, focusing on impacts to the aquatic, atmospheric and terrestrial biospheres that may occur and would need to be managed should the microalgae cultivation industry continue to grow.
\end{abstract}

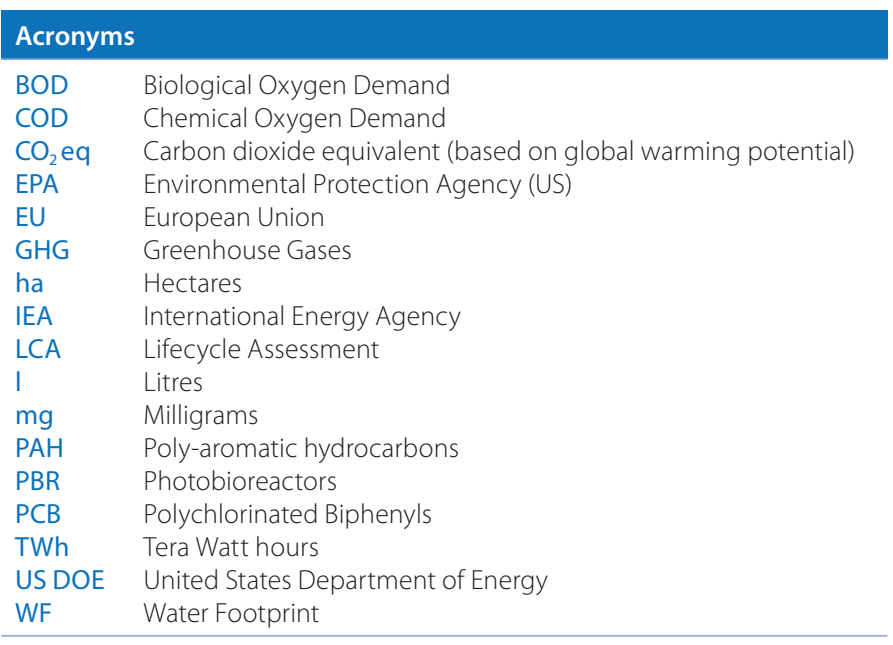

In a world where natural resources are being extracted and consumed at an ever increasing rate, there is also a growing need to seek alternatives to provide nutrients, chemicals and energy for mankind. Microalgae have gained attention due to their fast growing nature, adaptability to their environment and an ability to concentrate useful chemicals and capture nutrients in an economical way.

Microalgae are unicellular organisms found in marine and freshwater environments. They constitute

\footnotetext{
Energy Research Institute, University of Leeds, LS2 9JT, UK. 


\section{Key terms}

Anoxic - Total depletion of oxygen from a water body.

Axenic - A culture entirely free of contamination where only one species is present.

Bioaccumulation - Accumulation of a substance in an organism either from direct exposure or through consumption of a food source containing it.

Biodegradation - The decomposition or breakdown of organic material by microorganisms.

Bioengineering - Study and advancement of biological organisms using analytical and synthetic methods in order to solve real world problems.

Heterotroph - An organism that

cannot assimilate inorganic carbon, such as carbon dioxide, and uses an organic carbon source instead for growth.

Autotroph - An organism that converts sunlight to energy and biomass via photosynthesis. the most fundamental positions in aquatic ecosystems, and therefore form the basis of food chains. The total biomass they represent is large enough to influence global climate systems. Estimates suggest that over 800,000 species of microalgae exist, yet of these only 50,000 are documented [1]. Each species has adapted to a particular environment, for example extreme climates, salt levels, pH or light levels [2]. This demonstrates the enormous potential for modification of microalgae, which in turn may lead to an alternative resource pool for today's resource limited world.

As with all resources that are produced on a large scale, there are positive and negative impacts on the environment. There has been a broad scope of research based on microalgae, from microalgae as a biological resource to microalgae as a source of industrial and domestic wastewater clean-up, and from microalgae for the production of biofuels and fertiliser to microalgae for the production of food and pharmaceuticals. Fewer studies have looked into environmental impacts that could occur, should cultivation systems be scaled up. Some of the emerging research considers greenhouse gas emissions $[3,4]$, water consumption [5-7], and wastewater treatment [8-11]. There have been several recent reviews discussing the potential environmental impacts of different aspects of microalgal cultivation, for example the designing of pond-based cultivation systems using ecological principles to reduce environmental impacts [12], identification of environmental impacts and their social acceptance and perceived and actual health impacts [13].

The aim of this paper is to trace the impacts of large scale microalga cultivation systems through both primary and secondary stages and to highlight where there are uncertainties in estimating these impacts, as well as possible mitigation strategies. The focus of this review is on large open cultivation systems such as open raceway ponds.

This review begins with an overview of recent and current developments in the microalgae industry and an assessment of how biofuel policy will aid its development. Next, a comprehensive assessment of potential aquatic, atmospheric and terrestrial impacts is presented. A wide range of literature is reviewed in order to explore the potential complexities of interactions involved within and between each system. This review seeks to provide more detail on the specific impacts than has been provided previously, in particular identifying pollutants and uptake pathways in aquatic environments, specifying potential primary and secondary atmospheric emissions and investigating terrestrial impacts that could arise from large-scale microalgae cultivation in open systems. The impact of energy consumption and nutrient supply is discussed and the limitations in knowledge and understanding identified in the future perspectives. It brings together up to date academic and industrial research from these disciplines, enabling both researchers and policy makers to identify how to manage the impacts of large-scale microalgae growth in a way that will minimize further harm to the environment.

\section{Current situation}

Governments around the world are already legislating for the inclusion of biofuels within the transport fuel sector. Since 2008, EU policy has had a target of $10 \%$ of road transport fuel to be from renewable sources [14], although the UK government have only obliged retailers to include 5\% with no plans to increase this further [15]. Brazil, one of the largest producers of bioethanol and biodiesel, has reached $25 \%$ ethanol in gasoline blends as of May 2013 [16] and 5\% biodiesel in diesel blends since the beginning of 2013, eight years after first legislating for biodiesel inclusion into the fuel mix [17]. The US included 34 billion litres of renewable ethanol fuel in their gasoline blend in 2012, and have targets to increase this to 164 billion litres by 2022 [18]. By 2050, the IEA estimates $20 \%$ of liquid fuels will come from biofuels [19]. This level of demand for biofuels places enormous stress on biofuel producers in terms of land availability and resources for cultivation. A source of biofuel is sought, which may relieve some of these pressures.

The area of microalgae biotechnology is rapidly developing, attracting funding and investment worldwide. Examples shown in Table 1 indicate the range of products from large-scale microalgae cultivation and include a description of the different cultivation methods, sectors and location. Large-scale cultivation facilities for the production of nutritional supplements are predominant as these are economically feasible due to the high value end product (e.g. pigments and nutrients). Over $80 \%$ of the world's green algae producers are currently located in Taiwan, with Inner Mongolia in China and Israel being the top three producers of Dunaliella worldwide [20]. The use of large-scale microalgae cultivation for wastewater treatment is being developed in some regions and this is discussed in more detail later. There is funding from governments in the US, EU, Brazil, China, India, Canada and other countries worldwide in both universities and commercial facilities. Many 


\begin{tabular}{|c|c|c|c|c|}
\hline Algae & Cultivation & Industry/Product & Location & Link \\
\hline Dunaliella & Closed (PBR) & $\begin{array}{l}\text { Nutraceutical } \\
\text { ( } \beta \text {-carotene) }\end{array}$ & Israel & nikken-miho.com \\
\hline Dunaliella & Open (Raceway) & $\begin{array}{l}\text { Nutraceutical } \\
\text { ( } \beta \text {-carotene) }\end{array}$ & Australia & {$[22]$} \\
\hline Haematococcus & Open (Raceway) & Nutraceutical (Astaxanthin) & Israel & www.algatech.com \\
\hline Haematococcus/ Spirulina & Open (Raceway) & $\begin{array}{l}\text { Nutraceutical } \\
\text { (Astaxanthin/ Dietary } \\
\text { supplement ) }\end{array}$ & Hawaii & www.cyanotech.com \\
\hline Haematococcus & Closed (PBR) & Nutraceutical (Astaxanthin) & Sweden & www.bioreal.se \\
\hline Spirulina & Open (Raceway) & $\begin{array}{l}\text { Nutraceutical } \\
\text { (Dietary supplement) }\end{array}$ & USA (California) & www.earthrise.com \\
\hline Spirulina/Chlorella & $\begin{array}{l}\text { Open (Centre Pivot } \\
\text { Ponds) }\end{array}$ & $\begin{array}{l}\text { Nutraceutical } \\
\text { (Dietary supplement) }\end{array}$ & Taiwan & www.wilson-groups.com \\
\hline Chlorella & Closed (PBR) & $\begin{array}{l}\text { Nutraceutical } \\
\text { (Dietary supplement) }\end{array}$ & Germany & www.algomed.de \\
\hline Cyanobacteria & Closed (PBR) & $\begin{array}{l}\text { Biofuel } \\
\text { (Ethanol, diesel, jet fuel) }\end{array}$ & USA (Florida) & www.algenolbiofuels.com \\
\hline Unknown & Closed (Cultivation Bags) & $\begin{array}{l}\text { Biofuel } \\
\text { (Jet fuel) }\end{array}$ & $\begin{array}{l}\text { USA (New } \\
\text { Mexico) }\end{array}$ & www.sapphireenergy.com \\
\hline Unknown & Closed (Heterotrophic) & $\begin{array}{l}\text { Biofuel } \\
\text { (Biodiesel) }\end{array}$ & Brazil & solazyme.com \\
\hline Unknown & Open (Biofilm) & Wastewater treatment & USA (Florida) & www.aquafiber.com \\
\hline Unknown & Open (Raceway) & Wastewater treatment & New Zealand & $\begin{array}{l}\text { www.aquaflowgroup. } \\
\text { com/projects/blenheim- } \\
\text { municipal-wastewater }\end{array}$ \\
\hline
\end{tabular}

petro-based companies including Exxon, Shell, BP, Statoil, ENAP, Chevron are investing in biofuel R\&D for production of methanol, ethanol, bio-butanol, biodiesel, and biocrude as well as bio-based chemicals [21].

Production of biofuels from microalgae will require a scale of production that will inevitably have impacts on the environment. Various components of the microalgae structure can be used to produce different fuel types, using similar technology to that which is currently used for other bioenergy crops. Microalgae have cultivation benefits compared with other bioenergy crops because of their high growth rates and the option to use marginal land for cultivation. A report produced for the US DOE in 1984 looked at the chemical composition of eight strains of microalgae and calculated fuel production options based on their carbohydrate/protein/lipid content, demonstrating a combination of fuels that can be feasibly produced from an algal crop [23]. It is possible to produce biodiesel, bioethanol, biogas, bio-oil and even bio-hydrogen, as shown in Table 2 [24]. The energy content of biofuels from microalgae is comparable to those from other bio-crops and also fossil fuels. A summary of the energy contents is given in Table 2, based on an assumption of the following energy values for each characteristic: $38.93 \mathrm{MJ} / \mathrm{kg}$ for lipids, $23.86 \mathrm{MJ} / \mathrm{kg}$ for proteins and $15.92 \mathrm{MJ} / \mathrm{kg}$ for carbohydrates [23]

In order to identify the research needs for the successful production of microalgal biofuels, the US DOE developed a roadmap for algae biofuels. Within it, they described the need to understand the scale of benefits microalgae could bring if it were to be included into a fuel mix. It also looked at how microalgal biofuels can be introduced, taking into account the challenges still to be overcome [25]. The main conclusions reached demonstrated the need for far more research but also highlight the potential for microalgae to be developed into a competitive feedstock for biofuels.

\section{Potential environmental impacts}

- Aquatic impacts

When evaluating the environmental sustainability of an aquatic-biomass based cultivation system, indicators such as water quality requirements and water consumption need to be considered. For microalgae 
Table 2. Energy content of fuels from microalgae compared with existing biofuels.

\begin{tabular}{|c|c|c|c|}
\hline Fuel type $^{a}$ & $\begin{array}{l}\text { Energy content } \\
(\mathrm{MJ} / \mathrm{kg})\end{array}$ & Technologies & \\
\hline Biodiesel from algae & $35-41$ & Transesterification & {$[23][26]$} \\
\hline Bioethanol from algae & 23.4 & Fermentation & {$[23]$} \\
\hline Biogas from algae & 37.2 & $\begin{array}{l}\text { Anaerobic digestion, } \\
\text { hydrothermal treatment }\end{array}$ & {$[23]$} \\
\hline Bio-oil from algae & $33-39$ & $\begin{array}{l}\text { Hydrothermal } \\
\text { liquefaction }\end{array}$ & {$[27]$} \\
\hline Hydrogen from algae & 144 & $\begin{array}{l}\text { Biological production, } \\
\text { hydrothermal processing }\end{array}$ & {$[28]$} \\
\hline Biodiesel from soya & 37.2 & Transesterification & [29] \\
\hline Gasoline & 45 & Distillation of crude oil & [30] \\
\hline Diesel & 48 & Distillation of crude oil & {$[30]$} \\
\hline
\end{tabular}

aThe final energy density of the refined fuels is dependent on the composition of lipids and the biochemical composition of the starting microalgae

cultivation, water quality requirements vary depending on alga strains. It is possible to use low-grade wastes as a water source, in order to reduce pressure on natural water resources (i.e., industrial and/or domestic wastewater) $[8,9,11,24,31-35]$. Sewage is abundant in most countries, although collection and treatment methods vary; generally speaking, $75 \%$ of all wastewater generated worldwide is discharge without treatment into surface water bodies with high negative impacts to the environment and human health [36]. In the UK for instance, domestic water consumption is about $150 \mathrm{l} /$ person/day, resulting in $120 \mathrm{l} /$ person/day of wastewater going into sewers, to nearly 9000 wastewater treatment plants and returning to surface water sources [37]. Using domestic and industrial wastewater sources could be economically and environmentally beneficial for large-scale microalgae cultivation, as this practice could provide low-cost water and nutrients as well as wastewater remediation.

Microalgae are highly adaptive to their environment and thrive by utilising nutrients available in the water body. A high surface area to volume ratio gives algae the potential to absorb large amounts of nutrients across their surface, enhancing photosynthesis. The demand and rate of uptake of a nutrient depends on the strain and environmental conditions (e.g. temperature, light, limiting nutrients, etc.).

Carbon is an essential nutrient required for biomass formation. It can be acquired by photosynthetic microalgae in an inorganic form from carbon dioxide via carboanhydrase activity. However, carbon dioxide has low solubility in water and the poor net mass transfer from the atmosphere makes it a limiting nutrient for microalgae cultivation. The use of flue gas has been considered as an alternative to overcome that hurdle, but could create additional concerns on aquatic environments due to the dissolution of other pollutants. On the other hand, heterotrophic microalgae cannot assimilate carbon in the same way and requires an organic carbon source. In wastewater streams this would generally be by-products from bacterial degradation of organic matter like acetate, or other highly biodegradable organic compounds such as sugars from industrial sources - e.g. wastewater from food or drink industries.

Nitrogen is a key nutrient required by microalgae. Nitrogen assimilation is required for the formation of genetic material, energy transfer molecules, proteins, enzymes, chlorophylls and peptides. Most microalgae will assimilate inorganic nitrogen in the form of ammonium nitrogen $\left(\mathrm{NH}_{4}^{+}\right)$, but when it runs out or is not available, they have the ability to utilise other inorganic nitrogen species such as nitrate $\left(\mathrm{NO}_{3}^{-}\right)$or nitrite $\left(\mathrm{NO}_{2}^{-}\right)$[35]. Nitrogen can be sourced from fertilisers produced via the Haber-Bosch process, or from wastewater streams from a range of industries, municipal and domestic sources. An excess of nitrogen in an aquatic environment can lead to uncontrollable microalgae blooms, which could develop toxic conditions (i.e., the presence of toxins from cyanobacteria, free ammonia which is toxic to fish and low oxygen concentrations during the night due to algal respiration); therefore, nitrogen recovery from wastewater via biological uptake for algal biomass production may contribute to alleviate such negative impacts. A limited nitrogen supply however can limit algal growth and could affect lipid accumulation $[1,38-41]$. The compromise between growth and lipid accumulation has to be addressed and is significant as biodiesel production from microalgae generally requires high lipid content. Phosphorus is also required for energy metabolism. In many freshwater bodies phosphorus is a limiting nutrient, therefore excess phosphorus can lead to eutrophication [42], compared with marine environments where nitrogen is the growth limiting nutrient [43]. Phosphorus is a non-renewable resource which only exists in an inorganic form and must be either mined or recovered from waste. Phosphorus supplies are controlled by a handful of countries, meaning supply is influenced by international policy. Therefore phosphorus recovery will become essential for fertiliser due to limited resources and for the sake of geopolitical stability [44-47].

Phosphorus recovery by microalgae could present a particular environmental advantage for microalgae over other methods of $\mathrm{P}$ recovery. The use of microalgae could allow the recovery of low levels of $\mathrm{P}$ from sources in which other methods may be less economically viable. 


\section{Wastewater treatment}

Microalgae cultivation can feasibly be used as a secondary treatment process for various wastewaters, as algae are able to cope with particular pollutants. A summary of the potential pollutants found in wastewater, and their impact on humans, animals and microalgae is given in Table 3. The use of microalgae as a treatment method reduces the need for energy intensive cleaning processes and chemical use as is standard in wastewater treatment across the world. The mechanisms for nutrient removal depend on species but are generalised here to give a sense of the extent to which microalgae can be used for wastewater clean-up, and the problems faced. Waste Stabilization Pond Systems are one of the most popular and well established technologies for wastewater treatment using microalgae.

Algae from this system could potentially provide a low-cost feedstock for biofuels, as domestic wastewater contains valuable nutrients to support algae growth [48]. Human waste (i.e., urine and faeces) represents an important source of nitrogen and phosphorus, which are produced at a rate of 4.5 and $0.75 \mathrm{~kg}$ per person per year, respectively [49]. Considering the extensive use of P-rich detergents, phosphorus compounds appear in excess in raw sewage, making nitrogen a limiting nutrient for algae growth. The average composition of nitrogen in algal biomass varies between 6 and $10 \%$ dry weight [50], resulting in a potential algal biomass production from domestic wastewater ranging between 45 and $75 \mathrm{~kg}$ per person per year (i.e., equivalent to a potential global production of 315-525 Mton of algal biomass per year) [48].

Biological nutrient uptake by microalgae represents an added value to wastewater remediation. A recent study conducted in Taiwan showed complete $\mathrm{N}$ removal and 33\% removal of $\mathrm{P}$ was achieved by Chlamydomonas sp. [35] another study showed Chlorella sp. removed high levels of ammonia, total nitrogen, total phosphorus, and chemical oxygen demand (COD) in 14 days [10]. The removal of BOD and COD is attributed to either heterotrophic or mixotrophic algae. A further study showed strains that could remove organic carbon from the water, under mixotrophic conditions, leading to higher growth rates and lipid yields [33]. Cultivation of Euglena sp. in a wastewater facility in India yielded up to $28 \%$ lipids, composed of suitable fatty acids for biodiesel production [34]. Some studies have shown however that lipid yields can reduce under mixotrophic conditions [51].

Heavy metals, phenols, endocrine disruptors, antibiotics, polychlorinated biphenyls, viruses, antibiotics,

\begin{tabular}{|c|c|c|c|c|c|}
\hline & $\begin{array}{l}\text { Nutrient recovery } \\
(\mathrm{C}, \mathrm{N} \text { and } \mathrm{P})\end{array}$ & $\begin{array}{l}\text { Endocrine } \\
\text { disruptors }\end{array}$ & Heavy metals & Oils/grease & $\mathrm{PAH}^{\prime} \mathrm{s}^{*} / \mathrm{PCB}^{\prime} \mathrm{s}^{* *}$ \\
\hline Source & $\begin{array}{l}\text { Municipal, industrial or } \\
\text { animal wastewaters, } \\
\text { fertilisers, anaerobic } \\
\text { digestion effluent, } \\
\text { industrial exhaust gas. }\end{array}$ & $\begin{array}{l}\text { Pharmaceuticals, } \\
\text { plasticisers, } \\
\text { hormones, } \\
\text { pesticides, } \\
\text { polyaromatic } \\
\text { hydrocarbons } \\
\text { etc. [58]. }\end{array}$ & $\begin{array}{l}\text { Industrial wastewater, } \\
\text { mining, municipal } \\
\text { wastewater. }\end{array}$ & $\begin{array}{l}\text { Spills, mining } \\
\text { activity. }\end{array}$ & $\begin{array}{l}\text { Oil/coal industry, } \\
\text { diesel/gas engines, } \\
\text { incinerators, asphalt } \\
\text { production, coke } \\
\text { stoves [59]. }\end{array}$ \\
\hline $\begin{array}{l}\text { Potential effects of } \\
\text { excess in humans/ } \\
\text { animals }\end{array}$ & $\begin{array}{l}\text { Nitrates can cause } \\
\text { methemoglobinemia } \\
\text { [60]. Excess phosphorus } \\
\text { can lead to kidney } \\
\text { damage in animals [61]. }\end{array}$ & $\begin{array}{l}\text { Neurological } \\
\text { effects, birth } \\
\text { defects, } \\
\text { reproductive health } \\
\text { problems [62]. }\end{array}$ & $\begin{array}{l}\text { Bio-accumulates in } \\
\text { food chain. } \\
\text { Range of health } \\
\text { impacts. }\end{array}$ & $\begin{array}{l}\text { Variable toxicity. } \\
\text { Potentially lethal } \\
\text { to aquatic wildlife. } \\
\text { Bioaccumulation } \\
\text { issues [63]. }\end{array}$ & $\begin{array}{l}\text { Carcinogenic, } \\
\text { mutagenic, and } \\
\text { teratogenic [64]. }\end{array}$ \\
\hline $\begin{array}{l}\text { Effects in } \\
\text { microalgae }\end{array}$ & $\begin{array}{l}\text { Enhanced biomass } \\
\text { accumulation, } \\
\text { changes in biomass } \\
\text { composition } \\
\text { depending on water } \\
\text { composition } \\
\text { Eutrophication or } \\
\text { population collapse. }\end{array}$ & $\begin{array}{l}\text { Enhanced growth in } \\
\text { cyanobacteria } \\
<100 \mathrm{mg} \text { has no } \\
\text { affect in marine } \\
\text { microalgae } \\
>1 \mathrm{mg} / \mathrm{l} \\
\text { photosynthesis } \\
\text { completely } \\
\text { inhibited in marine } \\
\text { microalgae [58]. }\end{array}$ & $\begin{array}{l}\text { Sulphur accumulation } \\
\text { Metal recovered by } \\
\text { microalgae could } \\
\text { limit application of } \\
\text { microalgae Metals } \\
\text { detected include: } \\
\mathrm{Cd}^{2+}, \mathrm{Ag}^{2+}, \mathrm{Bi}^{3+}, \mathrm{Pb}^{2+} \text {, } \\
\mathrm{Zn}^{2+}, \mathrm{Cu}^{2+}, \mathrm{Hg}^{2+} \\
{[9,65] .}\end{array}$ & $\begin{array}{l}\text { Prolonged } \\
\text { growth phase, } \\
\text { higher biomass } \\
\text { production [54]. }\end{array}$ & $\begin{array}{l}\text { Bio-accumulation and } \\
\text { bio-transformation of } \\
\text { PAH's (highly species } \\
\text { specific). } \\
\text { PCB's accumulate in } \\
\text { lipids [54]. }\end{array}$ \\
\hline
\end{tabular}




\section{Table 4. Water footprint of different transport fuels.}

\begin{tabular}{|lll|} 
& $\begin{array}{l}\text { Average annual water } \\
\text { footprint (m3/GJ) }\end{array}$ & Source \\
Natural gas & 0.11 & {$[71]$} \\
Petroleum diesel & $0.04-0.08$ & {$[5]$} \\
Soybean biodiesel & 287 & {$[6]$} \\
Sugarcane ethanol & $85-139$ & {$[6]$} \\
Microalgae biodiesel (open raceway) & $14-87$ & {$[5][6]$} \\
Microalgae biodiesel (closed bioreactor) & $1-2$ & {$[6]$} \\
\hline
\end{tabular}

pesticides, oils and greases, have all been detected in either industrial or domestic wastewater sources [9,52-54]. Microalgae respond to these in different ways, from bioaccumulation to biodegradation and inactivation [54]. Compound uptake is highly species-specific, with toxic concentrations varying for different applications. Heavy metals can severely inhibit photosynthesis by blocking or replacing prosthetic metal atoms in enzyme active sites [55]. On the other hand, it has long been known that microalgae can be used to remove pesticides from water sources [56]. Bioengineering of microalgae and cyanobacteria could lead to further pollutant removal from water bodies [54]. However, it could compromise the use of microalgae in further applications (e.g. fuel, food, pharmaceuticals, etc.) if toxic compounds were found to bioaccumulate leading to their release either through emission from combustion or ingestion [13]. Examples include accumulation of heavy metals by Chlorella $s p$. and Scendesmus [57] and uptake and biodegrading of organic pollutants by $C$. reinhardtii [54].

\section{Viruses, pathogens and parasites}

Viruses affecting microalgae are thought to be ubiquitous in aquatic environments and function as an ecological mechanism for controlling microalgae populations [66-68]. This could lead to two impacts for large-scale microalgae cultivation. On the one hand it may lead to a population collapse, thus resulting in loss of the product and knock on effect on the supply chain for which it was intended. On the other hand, viruses could be used to control algal blooms.

Pathogens will coexist with microalgae. Where water is sourced from waste streams, particularly municipal or animal waste, there is a high chance that pathogens may be present in the harvested biomass or in final process effluent, despite the fact that algae cultivation in open ponds has the capacity to inactivate pathogens [69]. This will affect the end use of the microalgal product, or at least the post-treatment it must receive before it can be used in any product where it can present a potential health risk. There are also occupational health hazards for those managing the algal farms [13]. Parasites may threaten the health of the microalgae culture. One such example is $A$. protococcarum which was identified as being a risk to microalgal cultures. Research found the parasite is diverse and requires further research to understand its behaviour in order to protect microalgal cultures [70].

\section{Water footprint (WF)}

A water footprint is the total amount of fresh water embedded in the production of goods and services and includes both surface and groundwater (blue water footprint) and rainwater (green water footprint). Calculation of WF is highly sensitive to evaporation rates, hydraulic retention time and also the photosynthetic efficiency, which depends on climate, process design and cell biology. For example, the evaporation rate from an open system will vary depending on the local climate from $0.48 \mathrm{~m}^{3} \mathrm{~m}^{-2} \mathrm{yr}^{-1}$ to $2.28 \mathrm{~m}^{3} \mathrm{~m}^{-2} \mathrm{yr}^{-1}$ in arid regions [7].

The WF of a closed photobioreactor for biofuel production was found to be lower for microalgae biofuels than for other biofuels such as soya or palm biodiesel, or bioethanol from sugarcane, as shown in Table 4. The range indicates values from wastewater and seawater (lowest values) to freshwater (highest value). This confirms wastewater is essential to uphold the sustainability, both environmentally and economically of microalgaebased biofuels, in terms of clean water consumption and nutrient provision [5].

\section{Impacts to aquatic biodiversity}

Mass cultivation of microalgae can be termed as a "controlled eutrophication process", and as such needs to be well managed via adequate air supply and regular harvesting [131]. However, eutrophication remains one of the main risks to biodiversity. Decomposition of dead algal biomass consumes oxygen from the water column, leading to the asphyxiation of organisms depending on oxygen for respiration. The impacts of eutrophication include reduction in biodiversity due to hypoxia, water toxicity and turbidity. Methane production can occur in the anaerobic layers leading to odorous emissions (e.g. $\mathrm{H}_{2} \mathrm{~S}$ ) and greenhouse gases (e.g. $\mathrm{CH}_{4}, \mathrm{CO}_{2}, \mathrm{~N}_{2} \mathrm{O}$ ) with a strong global warming potential, as shown in Table 5. Any organisms' dependent on oxygenated waters can also be lost and replaced by other dominant species [132]. Accidental release of water from cultivation sites into the wider environment could lead to eutrophication events on a larger scale, particularly if cultivation takes place near a large water body such as a lake or a coastal area. The impact depends on the size of the release and quality of the receiving water body. For example, nutrient rich marine waters can reduce seagrass communities, which are essential for stabilising 


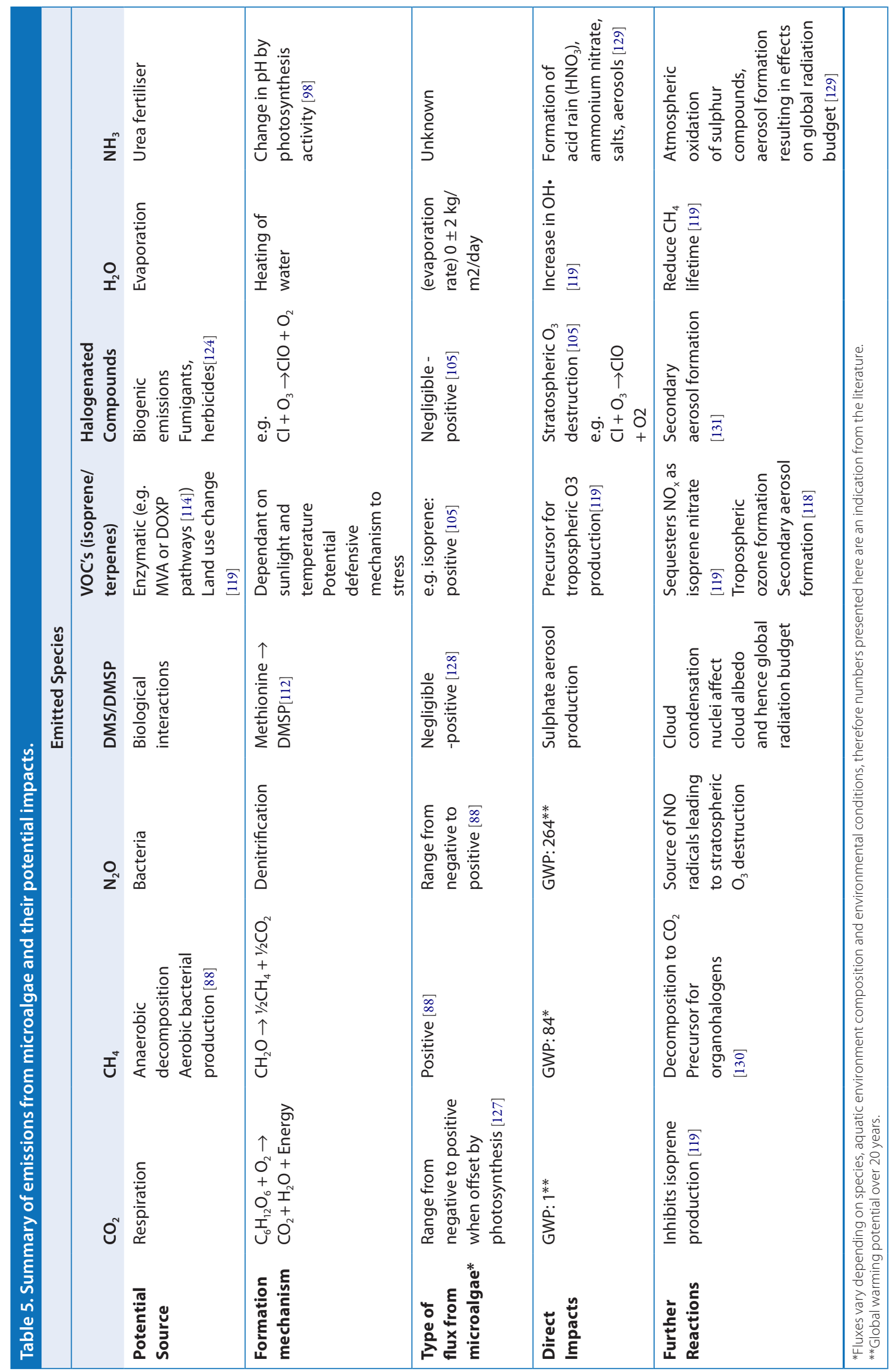


sediment and providing habitats and food sources for much marine life [12].

Open ponds are vulnerable to contamination. This risk can be minimised by altering culture conditions, making them unfavourable to native species. However, the release of non-native species could lead to problems particularly where they can out-compete native species. In some cases, introducing large volumes of water to otherwise arid regions could lead to a change in local climates. Higher evaporation rates would change humidity and temperature in these locations [13], as well as changing the biodiversity in the area, for example attracting animals and birds for drinking water, as well as breeding grounds for insects and other water wildlife. In either case discussed here, it is crucial that cultivation systems are well maintained and managed.

\section{- Terrestrial impacts}

Biofuel production has met with controversy regarding displacement of food crops for production of fuel. A key selling point for microalgal biofuels is the reduction of land needed to grow the same quantity of fuel given faster growth rates and higher yields per unit area than terrestrial crops. Many of the initial claims made for the amount of biofuels used prediction based on small-scale cultivation [65]. Estimates by [72] suggest an oil production rate of $5775 \mathrm{~L} \mathrm{ha}^{-1} \mathrm{yr}^{-1}$ (4620 L ha $\mathrm{yr}^{-1}$ of biofuel considering the $80 \%$ conversion efficiency) which is significantly lower than other published estimates. A study suggests that under current technology, microalgae have the potential to generate $220 \times 10^{9} \mathrm{~L} \mathrm{yr}^{-1}$ of oil, equivalent to $48 \%$ of current US petroleum imports for transportation based on consumption in 2011 [72]. It is estimated that to replace $50 \%$ of US transport fuels, $1540 \mathrm{M}$ ha of land would be needed for biodiesel from corn, $594 \mathrm{M}$ ha for biodiesel from soybean, yet around $43 \mathrm{M}$ ha for biodiesel from microalgae [72,73].

\section{Land use change (direct and indirect)}

The criteria for site selection for microalgae cultivation are defined by [1] to be a water supply with appropriate salinity and chemistry, suitable land topography, geology and ownership, good climatic conditions and easy access to nutrients and carbon supply. A map has been developed illustrating where all these criteria can be met. All areas identified as suitable are within the tropics, where there is a critical mass of population to provide the nutrients required through wastewater, and varied between inland and coastal locations [74]. Desert areas, such as southern Mediterranean countries, parts of the US and Africa could be used due to high ambient temperatures. There would however be a problem with freshwater supply. One study has evaluated the available water sources in the US in order to evaluate the land available for microalgae cultivation, and to assess how well the availability would meet with the demand for fuel. They conclude that within the US, despite higher productivities than other biocrops, land availability still challenges the ability to provide enough fuel from microalgae as a sole feedstock [72,75].

Whilst a good part of this could be on marginal land as described above, there would inevitably be changes to existing land use including pasture and forested areas. Direct land use change measures the direct GHG emissions caused from changing from one land use to another, for example how building raceway ponds on arable land leads to changes in gas fluxes. Indirect land use change occurs where land previously used to cultivate food is used to grow fuel crops, hence displacing food production to another area of land. The indirect change is the change in use of the land the food will now be grown on and any associated emissions. In 2012 EU member states agreed to report indirect land use change by fuel suppliers into GHG figures [76]. Off-shore cultivation of algae would avoid displacement of any land for biofuel or food production. Whilst few systems have been trialled to date, research group "Submariner" have been investigating the possibilities of linking both macro- and microalgae cultivation containment infrastructure with an existing offshore wind farm in the Baltic Sea as a way of reducing pressure on land availability [77-79].

\section{Contamination and leaks}

There are many designs for reactors. Open ponds allow large scale cultivation at lower cost. However, the open design makes them vulnerable to contamination. This risk can be minimised by altering culture conditions, making them unfavourable to native species. Ponds that are not correctly designed or constructed could pose a threat to the direct environment from leaching of the pond contents into the ground. Examples include salinisation in situations where marine algae are cultivated on land, or loss of toxicants where microalgae are also being used as a wastewater treatment facility [13]. Whilst the content of the ponds would not necessarily be toxic, it may lead to contamination of ground water. Photobioreactors (PBRs) are translucent containers that allow light to penetrate to the microalgae. PBRs are closed, therefore are less susceptible to contamination. Depending on the volume, a leak from these containers could also have a significant impact, for example if located near a natural source of water. However, it would be potentially easier to detect and therefore easier to rectify. 


\section{Impacts to terrestrial diversity}

The construction of ponds could also lead to the displacement of local fauna through destruction of habitat. Environmental Impact Assessment surveys can be used to assess the level of impact the construction of largescale ponds would have. The NRC identified the effects on terrestrial biodiversity from changing the landscape pattern as a result of infrastructure development for algal biofuels [13]. An example of a how a large water project has affected local biodiversity is that of reservoir construction. Whilst the size of reservoir construction is greater than the expected change from microalgal ponds, it provides a guide as to what some of the changes could be. For example, a scoping resort for the proposed development of the Havant Thicket Winter Storage Reservoir in Hampshire (UK) found ecological issues to include loss of ancient woodland and other flora, losses of individual species during site clearance or construction, damage to habitats as a result of accidental pollution, disturbance of species from the presence of traffic, machinery or humans and fragmentation of habitat with loss of connectivity between habitats [80]. It is likely the development of a large-scale facility would also face some of these challenges, in particular damage to habitats, including pollution, and disturbance by the presence of human activity.

\section{- Atmospheric impacts}

Whilst the direct impacts of microalgae cultivation are most apparent to water and land systems, large-scale microalgae cultivation also has a range of potential impacts on the atmosphere. The scale of the impact will depend largely on the type of cultivation system. This section looks at potential gaseous and aerosol emissions from microalgae cultivation as well as the potential to reduce greenhouse gas emissions by their uptake during cultivation. It also looks at direct impacts and further atmospheric reactions that can take place as a result of the pollutant species emitted. A summary of the main species emitted is given in Table 5.

\section{Carbon dioxide}

Large-scale cultivation of microalgae could potentially enhance the biological fixation of $\mathrm{CO}_{2}$ via photosynthesis. A number of studies have quantified the scale at which microalgae can contribute to carbon uptake from the atmosphere and have found the uptake rate varies between organisms. For example, [81] found the diatom $P$. tricornutum had a low carbon uptake rate of $1.5 \mathrm{mg} \mathrm{l}^{-1} \mathrm{~min}^{-1}$ compared with a $28 \mathrm{mg} \mathrm{l}^{-1} \mathrm{~min}^{-1}$ by cyanobacteria $A$. microcopia Nageli. Microalgae will also produce $\mathrm{CO}_{2}$ via respiration. A surface response methodology developed by [82] quantified the contribution microalgae could have for $\mathrm{CO}_{2}$ uptake, if grown at optimum conditions. Using these figures and updating to 2013 levels of global $\mathrm{CO}_{2}$ emissions; to remove $2.5 \%$ of emissions from the atmosphere (that is $900 \mathrm{~m} \mathrm{tCO}_{2}$ ) requires $65,800 \mathrm{~km}^{2}$ land, equivalent to $0.43 \%$ global arable land (as defined at $15.3 \mathrm{~m} \mathrm{~km}^{2}$ by the UN/FAO in 2009).

Using microalgae as a $\mathrm{CO}_{2}$ treatment method for flue gases has also been investigated. A study looked into the possibility of using the $\mathrm{CO}_{2}$ produced from an ethanol factory for microalgae cultivation in Iowa, demonstrating it was technically possible [83]. Microalgae can be used to separate the $\mathrm{CO}_{2}$ out of the gas stream, rather than using an expensive chemical method [55]. When paired with another industry, this becomes economically attractive, particularly if carbon trading becomes a significant economic driver. However, other components of the flue gas could be problematic, for example $\mathrm{NO}_{\mathrm{x}}$ and PAHs, in a similar way as discussed in Table 3.

\section{Methane emissions}

There are only a few studies of methane emissions from large-scale microalgae facilities. Basic measurements from wastewater treatment plants, lakes or oceanic emissions could give an indication of potential levels of emissions $[4,84,85]$. However, due to the limited research in this area we are unable to give a reasonable estimate. Methane $\left(\mathrm{CH}_{4}\right)$ is another potent greenhouse gas with a global warming potential over a 20 year period of 84 and therefore large-scale emissions are of concern in the context of climate change. Methane also contributes to the formation of background ozone which has both air quality and climate implications [86].

It is widely acknowledged that methane is produced via anaerobic decomposition by methanogenic bacteria. In a well-managed microalgae system, it would not be expected that any anaerobic conditions would exist due to constant aeration of the water. Therefore the production of aerobic methane is of particular interest when calculating the potential greenhouse gas emissions from microalgae cultivation. However, aerobic production of methane was discovered in 2006, and is not a microbial process but rather an in situ process in living plants [87]. Studies have found that $\mathrm{CH}_{4}$ is usually supersaturated above the surface water across the planet with respect to atmospheric levels, and have demonstrated that it is produced by the water under oxic conditions [85,88]. Therefore, any scale of microalgal cultivation facility is likely to make some contribution to $\mathrm{CH}_{4}$ emissions to the atmosphere.

\section{$\mathrm{N}_{2} \mathrm{O}$ production}

$\mathrm{N}_{2} \mathrm{O}$ emissions from microalgae are of concern if they can be proved to be significant. $\mathrm{N}_{2} \mathrm{O}$ is 264 times more powerful than $\mathrm{CO}_{2}$ as a greenhouse gas over 
a 20-year period [86], and therefore of concern, should the emissions prove to be significant during cultivation.

Traditionally, two main routes have been proposed for $\mathrm{N}_{2} \mathrm{O}$ production during microalgal biomass cultivation under non-axenic conditions; this is either from autotrophic bacteria, which can use either hydrogen or sulphur compounds as the electron donor, or from heterotrophic denitrifiers, which can use organic compounds instead [89-91].

Generation of $\mathrm{N}_{2} \mathrm{O}$ by bacterial denitrification occurs through a series of reduction reactions, shown in equation (1) [3]:

$$
\mathrm{NO}_{3}{ }^{-} \rightarrow \mathrm{NO}_{2}{ }^{-} \rightarrow \mathrm{NO} \rightarrow \mathrm{N}_{2} \mathrm{O}
$$

However, there has only been a few studies into the production of $\mathrm{N}_{2} \mathrm{O}$ from microalgae cultivation. In open ponds of $N$. Salina, $\mathrm{N}_{2} \mathrm{O}$ levels were found to be negligible under oxic conditions, but they were increased where anoxic conditions develop [3]. The suggested route for $\mathrm{N}_{2} \mathrm{O}$ production was from denitrifying bacteria in the culture. Another study from raceway ponds in Hawaii found that when $\mathrm{NO}_{3}{ }^{-}$was depleted in a raceway pond cultivating Staurosira sp., the water body would become a sink of $\mathrm{N}_{2} \mathrm{O}$ rather than a source [88]. However, the same study concluded that the net $\mathrm{N}_{2} \mathrm{O}$ mass transfer from the atmosphere represented an insignificant fraction of the overall $\mathrm{CO}_{2}$ equivalent uptake by the microalgae culture. Whilst others suggest it may be possible to use antibiotic treatment to reduce $\mathrm{N}_{2} \mathrm{O}$ fluxes to the atmosphere due to bacterial denitrification, this would inevitably lead to water quality concerns in relation to antibiotic immunity [3].

More recently, fieldwork using stable nitrogen isotopes $\left({ }^{15} \mathrm{NO}_{2}{ }^{-}\right)$and conducted by [92] confirmed the importance of denitrification processes in wastewater algal ponds under UK winter conditions and suggested the role that microalgae may play in $\mathrm{N}_{2} \mathrm{O}$ production. In agreement with [93], it is very interesting that pioneering work confirming the potential release of $\mathrm{N}_{2} \mathrm{O}$ from axenic cultures of green algae by [94] and [95], has been forgotten for decades. Indeed, the evidence reported by [93] using Chlorella vulgaris to study the mechanisms controlling microalgae-mediated $\mathrm{N}_{2} \mathrm{O}$ production strongly suggests that nitrite intracellular accumulation and its reduction by Nitrate reductase trigger $\mathrm{N}_{2} \mathrm{O}$ emissions, which correlates with nitrite and nitrate concentrations and photosynthesis repression. These results also indicate the significant contribution that largescale microalgae cultivation can make to GHG emissions (e.g. $1.38-10.1 \mathrm{~kg} \mathrm{~N}_{2} \mathrm{O}^{-} \mathrm{N} \mathrm{ha}^{-1} \mathrm{yr}^{-1}$ in a $0.25 \mathrm{~m}$ deep raceway pond operated under Mediterranean climatic conditions) and reports a net carbon footprint for algal biofuel of 1.96-14.4 $\mathrm{g} \mathrm{CO}_{2}$ equivalent MJ fuel ${ }^{-1}$ [93].

A further source of $\mathrm{N}_{2} \mathrm{O}$ exists where microalgal biomass (either lipid extracted or digestate from biogas production) is used as a fertiliser for nutrient recycling [96]. A study, following methods suggested in the IPCC AR4 report, calculated that the use of microalgae digestate as a fertiliser can cancel any GHG saving benefits gained from displacing mineral fertilisers [84].

\section{Ammonia volatilisation}

Ammonia $\left(\mathrm{NH}_{3}\right)$ is a reactive gas in the atmosphere as well as in water bodies. A recent European report on nitrogen pollution and the European environment suggests ammonia to be "a neglected pollutant" which is difficult to control [84]. Ammonia emissions across Europe are expected to decline by only $7 \%$ by 2020 compared with 2000, whilst $\mathrm{SO}_{2}$ emissions are expected to reduce by $72 \%$. Emissions of ammonia can contribute to the formation of ammonium salts and nitrate aerosols within the atmosphere and thus to the formation of PM2.5 (particulate matter that passes through a size-selective inlet with a $50 \%$ efficiency cut-off at $2.5 \mu \mathrm{m}$ aerodynamic diameter) [85]. Via deposition processes, atmospheric ammonia can lead to water pollution through surface run-off in the form of nitrites $\left(\mathrm{NO}_{2}^{-}\right)$, nitrates $\left(\mathrm{NO}_{3}{ }^{-}\right)$, and ammonium $\left(\mathrm{NH}_{4}^{+}\right)$and dissolved organic nitrogen potentially contributing to soil acidification, the leaching of soil nutrients, eutrophication and ground water pollution. Ammonia emissions could therefore be of potential concern for microalgae cultivation systems.

In aqueous solution, ammonia gas $\left(\mathrm{NH}_{3}\right)$ remains in equilibrium with its ionised form, ammonium $\left(\mathrm{NH}_{4}^{+}\right)$ and the relative concentration of ammonia increases over the concentration of ammonium when $\mathrm{pH}$ increases. Ammonia volatilisation has generally been reported as a main concern in open algal ponds, as it is assumed that ammonia nitrogen is lost to the atmosphere as a consequence of high in-pond $\mathrm{pH}$ values $(>9$, even $>10)$ [97,98]. However, such an assumption does not consider the role of nitrogen algal uptake and algae-mediated denitrification ( $\mathrm{N}_{2} \mathrm{O}$ emissions).

Theoretical ammonia volatilisation rates have been calculated based on numerical models; however, none of these models have been calibrated or validated by means of direct measurements of ex-pond ammonia volatilisation rates in situ, and ignore simultaneous biochemical processes affecting total ammonium concentrations. The work conducted in open wastewater algal ponds by [99-102] presents strong evidence supporting the fact that ammonia emissions due to volatilisation are likely to make a small contribution towards ammonia losses as most nitrogen is removed via biological uptake and or algal/bacterial denitrification. 
Another factor to be considered in this analysis is the poor conditions found in open algal ponds for gas mass transfer from in-pond water column to the atmosphere. In order to illustrate such conditions, it is valid to use the binary system oxygen-water for comparison with the system ammoniawater. In algal ponds, oxygen is produced by photosynthesis and when primary productivity reaches its maximum, it is very common to register oxygen concentrations higher than the saturation concentration (> 100\% dissolved oxygen saturation), as mixing conditions in open ponds are not vigorous and gas mass transfer is affected, resulting in gas accumulation in the water column. Considering that ammonia gas solubility in water $\left(480 \mathrm{~g} \mathrm{NH}_{3} / \mathrm{kg}\right.$ water at $25^{\circ} \mathrm{C}, 1$ Atm) is much higher that oxygen solubility $\left(0.04 \mathrm{~g} \mathrm{O}_{2} / \mathrm{kg}\right.$ water at $25^{\circ} \mathrm{C}, 1 \mathrm{Atm}$ ), it is expected that ammonia mass transfer from the bulk of the liquid would be even lower (i.e., ammonia and oxygen diffusivity in water are $1.24 \times$ $10^{-5}$ and $2.10 \times 10^{-5} \mathrm{~cm}^{2} \mathrm{~s}^{-1}$, respectively at $25^{\circ} \mathrm{C}, 1 \mathrm{Atm}$ ) [103]. However, it is expected that conditions in PBRs would be more favourable to gas mass transfer rates as they are vigorously mixed, but the lack of experimental data requires further research in that field.

\section{Biogenic halogenated emissions}

Organohalogens are derived from methane emissions, and therefore the level of methane emitted by a cultivation site may have a direct impact on the level of halogenated species. Whilst the majority of halogenated compounds are thought to be produced by macroalgae on coastlines, microalgae have also been shown to emit a range of brominated and iodinated species[104,105]. The mechanism by which organohalogens are formed is biomethylation with a halogen ion, where sulphonium compounds are considered to be the main $\mathrm{CH}_{3}{ }^{+}$donor [106]. Emissions could include dihalo- and trihalomethanes and further brominated and iodinated compounds [107].

Reactive halogen compounds can then be formed via the breakdown of organohalogens and impact on the oxidising capacity of the troposphere, as well as contributing to ozone depletion in the stratosphere $[108,109]$. Studies have also suggested that biogenic iodocarbon emissions may play a role in new particle formation in the atmosphere, thus contributing to secondary aerosol production [110]. The size of the flux of halogenated compounds has only been reported from a few sources and requires further investigation, but these studies prove that large-scale cultivation of microalgae, particularly on saline water, would have a certain degree of influence on the total halogenated species emission budget globally [111,105].

\section{Biogenic sulphur emissions}

Dimethylsulfoniopropionate (DMSP) is produced from marine algae, and degraded by marine bacteria to dimethylsulfide (DMS). The total flux of biogenic DMS to the atmosphere is between $28-45 \mathrm{Tg}$ of sulphur a year, the majority of this coming from the world oceans [112]. It acts as a precursor to sulphate aerosol production, which subsequently leads to a higher number of cloud condensation nuclei (CCN). More CCN leads to cloud formation and this in turn can affect local and even global climates by changing the global radiation budget $[111,113]$. Sulphate aerosol and cloud adjustments due to aerosols both have negative radiative forcing potentials relative to 1750 , in the Fifth Assessment Report by the IPCC, although the stated uncertainties are large [86]. The possible extent of large-scale microalgae cultivation systems may not be sufficient to contribute more than a small fraction of future emissions of DMS [86]. Whilst this may not be enough even to affect local climates, should there be a leakage from a cultivation site causing widespread algal blooms, the production could be enhanced.

Other volatile organic carbon (VOC) emissions

The production of isoprene by microalgae has been observed from microalgae cultivated in seawater [105,114]. Isoprene is formed via enzymatic catalysis by isoprene synthase [115]. Isoprene is highly reactive due to the presence of a double bond and its effects on the global climate have been modelled with increasing interest over the past decade [116-121]. For example, high concentrations of isoprene consume hydroxyl radicals, thus reducing their capacity to oxidize volatile organic compounds. This can lengthen the atmospheric lifetime (and hence climate change effects) of key global warming gases such as methane [122]. The presence of sunlight and $\mathrm{NO}_{\mathrm{x}}$ links VOCs to the production of tropospheric ozone $\left(\mathrm{O}_{3}\right)$, which has a positive radiative forcing potential [86].

Isoprene oxidation products have also been suggested to contribute to the formation and particle growth of secondary organic aerosols (SOA) which potentially have both air quality and climate impacts $[111,123]$. The amount of SOA formed is dependent of the level of oxidation, $\mathrm{NO}_{x}$ levels and organic aerosol loading. This could have an impact on the location of cultivation sites. If located near a source of $\mathrm{NO}_{x}$, for example road links or industry, the levels of SOA could be higher [118]. However, this cannot currently be estimated and further work on the link between $\mathrm{NO}_{\times}$and cultivation is required.

\section{Emissions from application of pest controls}

In order to maintain a healthy microalgae crop, particularly where an axenic culture is required, the use of herbicides, insecticides or fumigants may be employed. Pesticides contain organochlorine compounds which, as mentioned above, lead to ozone destruction in 


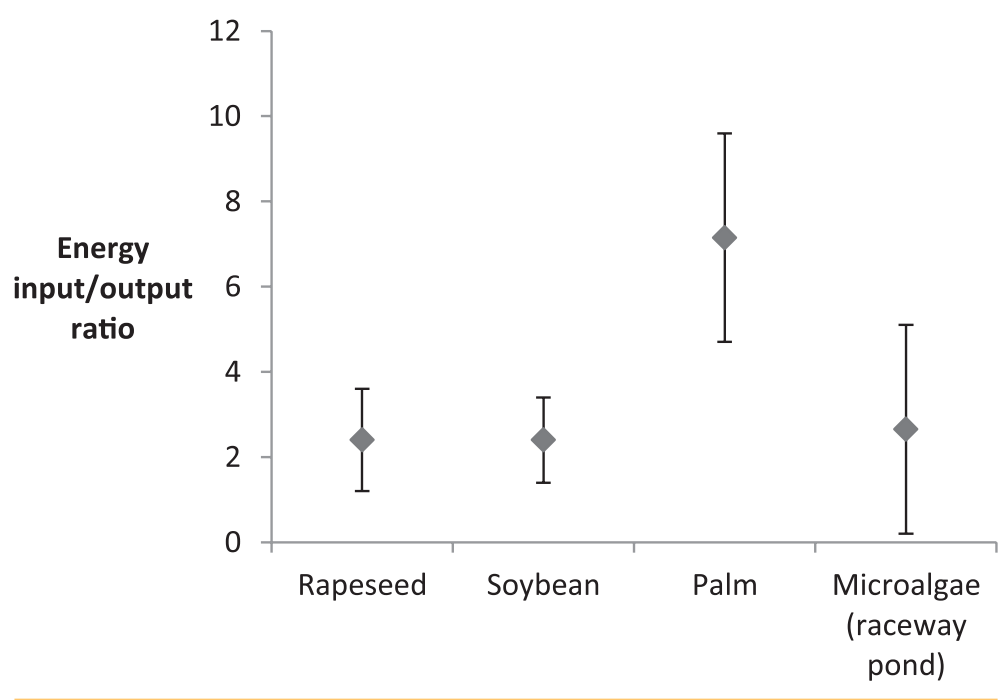

Figure 1. Energy ratio for production of biodiesel from different feedstocks. Data taken from $[61,121,125,126]$

the stratosphere [124]. However, it would be expected that the use of pest control would be lower compared with terrestrial agricultural crops [12] as some species produce metabolites that act as natural pest control mechanisms [125].

\section{Impacts of emissions to biodiversity}

Particulate emissions can lead to impacts on human health by affecting the air quality as well as impacts to crops, trees and fragile micro-ecosystems. For example, tropospheric $\mathrm{O}_{3}$, a by-product of VOCs has adverse effects for humans and wildlife, for example damaging effects for crops, adverse health impacts such as respiratory problems, and so on [126]. Ammonia is another problematic species for health and can pose a real threat to biodiversity. In particular the dry deposition of ammonia is suggested to be detrimental to sensitive ecosystems such as lichens and bryophytes.

\section{- Energy and nutrient supply}

The use of energy in microalgae cultivation has been referred to throughout the paper, as it is essential that the production of biofuel from microalgae has a positive energy balance. The associated GHG emissions are also of upmost importance as discussed earlier. GHGs are emitted if fossil fuels are used to provide the energy for conversion, for the supply of nutrients to sustain growth and for onsite operations. The source and quantity of energy needed for cultivation is key to making it a sustainable and low carbon technology.

Lifecycle assessments that consider energy use, fail to agree on an absolute figure for the amount of energy required to produce a certain quantity of biomass. Eight life cycle assessments from a range of authors were compared in terms of fossil energy input (MJ) per kg dry biomass from raceway ponds [132]. Each study used different conditions, and hence the energy requirement varied considerably. Figure 1 shows the relative energy requirements for biodiesel produced from different feedstock. Greenhouse gas emissions also depend on cultivation methods, and can range from lower than terrestrial crops to considerably higher than terrestrial crops. Typical values reported range from 0.4-4.4 $\mathrm{kgCO}_{2} \mathrm{eq} \mathrm{kg}^{-1}$ feedstock for microalgae compared with $0.4-0.5 \mathrm{kgCO}_{2} \mathrm{eq} \mathrm{kg}^{-1}$ feedstock for soybean for example [133-139].

In terms of energy demand for microalgal growth there is not a clear difference between the use of saline or freshwater sources [136-138]. However, there are significant energy input implications, associated with water use. The water-energy nexus is a relationship between the energy required to supply water and water required to produce energy. The energy to clean water is in the range of $5.4-25.55 \mathrm{kwh} \mathrm{m}^{-3}$ [140]. A study of the water requirements for biodiesel production from microalgae estimates between 1-11 billion $\mathrm{m}^{3}$ would be needed to achieve the target of 1 million $\mathrm{m}^{3}$ biodiesel [5]. This would lead to an energy demand of up to $281 \mathrm{TWh}$ if clean water were to be used, equal to $88 \%$ of the UK's electricity consumption for 2012. It is therefore likely that untreated wastewater will be used and this has the added benefit of supplying nutrients. The large-scale cultivation of fresh water microalgae for biofuels is likely to be limited in many regions due to the competing markets for water such as domestic and agricultural use. In which cases, the large scale cultivation of marine microalgae may be more feasible. The cultivation of marine microalgae however will still require water to compensate for the losses due to evaporation and this is likely to come from untreated fresh water to compensate for increases in salinity.

The choice of cultivator will affect the energy usage, affecting the overall GHG emissions associated with microalgae cultivation. A study comparing cultivation of $C$. Vulgaris in raceway ponds with PBRs in the UK found raceway ponds could be self-sufficient in terms of power generated from biogas to operate the ponds [139]. In contrast, PBR's would consume more energy than fossil-fuel derived fuels due to the production of the containers in which the microalgae would grow. A study used seawater to cultivate $N$. Salina in raceways and PBRs in Brazil, and found PBRs consumed over 15 times more energy for water pumping and cooling than raceways [136]. Other cultivation systems include algal turf scrubbers (water filtering devices used to cultivate algae) which are operated at full scale for wastewater 
treatment using filamentous algae, biofilm designs which aim to reduce energy and water use $[141,142]$ and heterotrophic fermentation systems. These are emerging technologies and are beyond the scope of this review.

Cultivation will have to take different forms depending on location. The climatic conditions within the tropics make outdoor cultivation more suitable due to longer sunshine hours throughout the year and higher temperatures. This can lead to cultivation at low costs as there is no need for heating or covering, and cultivation can continue year round. Outside of the tropics, productivity levels will fall where algae is cultivated outdoors during winter months. Other factors to take into consideration are co-location with nutrient or $\mathrm{CO}_{2}$ sources. As mentioned above, a map demonstrating where there were sufficient nutrients, $\mathrm{CO}_{2}$ and good climatic conditions to ensure productive growth was produced [74]. However, all suitable areas were within the tropics. Therefore, countries at higher latitudes may be better placed to develop heterotrophic systems where the environment can be controlled more carefully but yields are higher, making it more economically feasible.

The source of nutrients can vary by region maximising on a region's natural asset. Nutrient sources can include animal sludge, winery waste, distilleries, coffee plantations, textile factories or [domestic] wastewater among others [8]. Sources of organic carbon for mixotrophic or heterotrophic cultivation include sweet sorghum [143], rice hydrolyase [144] and sugar mills [145]. The use of waste streams has the joint environmental benefit of reducing energy and emissions required to produce virgin resources, and reducing energy requirements for water treatment.

LCAs have been carried out in countries around the world to quantify the environmental impacts of microalgae cultivation. In China, microalgae were found to beat soybean as a biodiesel feedstock in all environmental impact categories [146]. However a study in America contradicted this, stating that microalgae only perform more favourably in terms of eutrophication reduction than terrestrial crops, with higher greenhouse gas emissions, energy use and water consumption. The same study also looked at the use of wastewater and flue gases and demonstrated the need for waste resources to be used as inputs by modelling the impact of wastewater offsets [134]. Work in France found microalgae had lower impacts than terrestrial crops in some categories, such as eutrophication and land use, but it exceeded other crops' impacts in the categories of ionizing and photochemical oxidation, marine toxification, ozone depletion and biotic depletion when used as a biodiesel feedstock. Again, the increase in some of these impact categories is associated with fertiliser use [41].

\section{Future perspectives}

Microalgae could certainly provide potential environmental benefits when used instead of petrochemicals and terrestrial crops. Environmental benefits range from clean water from water treatment, to the substitution of fossil-fuel derived materials with microalgae components in fuels, foods and pharmaceuticals. There are however many potential disadvantages too, and the scale of these impacts remains unknown due to large gaps in the literature. A summary of some of the main potential environmental impacts is given here, along with identification of further research needed.

There is the issue of atmospheric emissions from the cultivation of microalgae at a large scale. The scale of the emissions is largely unknown, while the secondary reactions in the atmosphere remain as best guesses in many cases. However, the consensus is emissions will occur, and therefore they must be monitored and managed accordingly. There is the potential for uptake of $\mathrm{CO}_{2}$ by algae during the growth phase. Where the algae will be used for biofuel production, this can lead to a more neutral level of $\mathrm{CO}_{2}$ emissions compared with fossil fuel sources, reducing the contribution of $\mathrm{CO}_{2}$ to global climate change. The atmospheric impacts of an open system are expected to be significantly higher than closed systems as trapping of gaseous emissions may be possible. The trapping of gaseous emissions from photobioreactors is beyond the scope of this review.

Microalgae could be used as a wastewater treatment option. The issue arises whether microalgae are a more environmentally friendly and sustainable method of wastewater treatment than existing methods. Existing water treatment demands high levels of energy and chemicals and as a result is an expensive process, with significant environmental impacts. Microalgae can provide a lower cost alternative, whilst removing the demand for chemical use. However, a number of problems will arise as a result. The first is the potential of nutrient release in case of failure, leading to eutrophication in water bodies. There is also a link with the emmisios, in particular methane and $\mathrm{N}_{2} \mathrm{O}$, as discussed earlier. Further work is needed to identify triggers for methane production and quantify the fluxes.

Much work is needed to assess the accumulation of toxins in the biomass when it is grown on wastewater, as this could limit its use both in food and pharmaceuticals, as a fertiliser (in particular if it is used for the fertilisation of food crops) and also as a fuel feedstock where heavy metals or bioaccumulators could affect fuel properties and the composition of emissions, for example PCB accumulation in lipids as mentioned in Table 3.

The impact of large-scale microalgae cultivation on terrestrial biodiversity has not been extensively researched as noted by [13]. Displacement of wildlife 
for construction of ponds and changes to natural water quality caused by contamination from ponds are the main threats, but further assessment of the impacts are needed.

Genetic modification of microalgae has been appealing to some groups of scientists, especially due to the relative simplicity of the microalgae cell compared with higher plants, which have cell differentiation. So far a lot of attention has been paid to photosynthetic and metabolic pathways, particularly for antibody production and soil bioremediation. These species have been grown under controlled and concealed autotrophic and heterotrophic conditions [124]. Concerns about biological contamination restrict development of this area. Because of microalgae being one of the most fundamental parts of the ecosystem, a change in the natural ecosystem could have devastating effects for the whole food chain and beyond [126].

Finally, the question of whether it is feasible to produce fuel from microalgae from an energy balance standpoint needs to be addressed. The energy balance for fuel produced from microalgae looks promising, despite contradictions between many studies. Where biomass production is integrated with biogas production, a cultivation facility can become self-sufficient with respect to heat [138]. As mentioned, nutrient sources already exist in many countries that should be capitalised on to avoid unwanted eutrophication or disposal of these resources into landfill. Linking of industries is also essential to maximise environmental gain from microalgae, for example obtaining nutrients from waste streams in terms of flue gases, sewage or process waters, or heating from industrial processing. The location of microalgae farms is also an important factor and will depend on the availability of resources, land ownership and economic feasibility as well as taking into account the environmental effects.

There will inevitably be environmental impacts of large-scale microalgae cultivation, as this will require changes in land use and consumption of natural resources. The question is whether these impacts can be managed, and whether they will prove more or less damaging than the crops we currently produce for food, materials and fuel. There is a role for environmental policy to play in ensuring feedstock are well managed and therefore are a positive attribute in agricultural production. Certification will help guide producers and consumers as to which products are best to support, and educate the public and policy makers in the diverse uses microalgae can have [140]. It is also important to extend upon existing LCA work to define how best to measure the environmental impacts of microalgae, with more clarity given to system boundaries and allocation methods. Expansion of commercial and academic research networks will allow information to be shared to ensure progress is made in expanding microalgae cultivation and developing best practice for environmental management. Development of genetically modified organisms requires a joint effort between researchers, policy makers, industries and public stakeholders to avoid both poor public perception and irresponsible use.

\section{Executive summary}

\section{Background}

- Governments are keen to promote biofuel uptake as a way to reduce greenhouse gas emissions and reduce dependency on fossil fuels.

- Microalgae are becoming a contender for biofuel production, with growing levels of research and investment in large-scale demonstration and some commercial-scale projects.

- Large scale cultivation will cause changes to the environment, which may have short- and long-term impacts on biodiversity, resource availability and local to global climate.

Aquatic impacts

- Microalgae have been proved to be effective at recovering a range of compounds from wastewater, demonstrating a potential as a water clean-up method.

- Treatment of water could lead to bioaccumulation of excess nutrients and potentially toxic compounds including PAHs, PCBs, hormones, oils, etc. However, uncontrolled cultivation could lead to blooms, and disease or pest could lead to population crashes leading to loss of product and clean-up operations being required.

Atmospheric impacts

- Microalgae offer a method for biofixation of carbon dioxide. $\mathrm{CO}_{2}$ could be sequestered directly from the atmosphere and from flue gases, providing a gas clean-up method too.

- Biogenic emissions have been observed from microalgae including isoprenes, terpenes and organohalogens. Research into the scale of these fluxes is in the early stages of development, but must be continued as these compounds are precursors to ozone destruction and low level ozone formation.

- Location of cultivation sites should be assessed based on other local sources of emissions, as combinations of pollutants could lead to formation of secondary organic aerosols. 


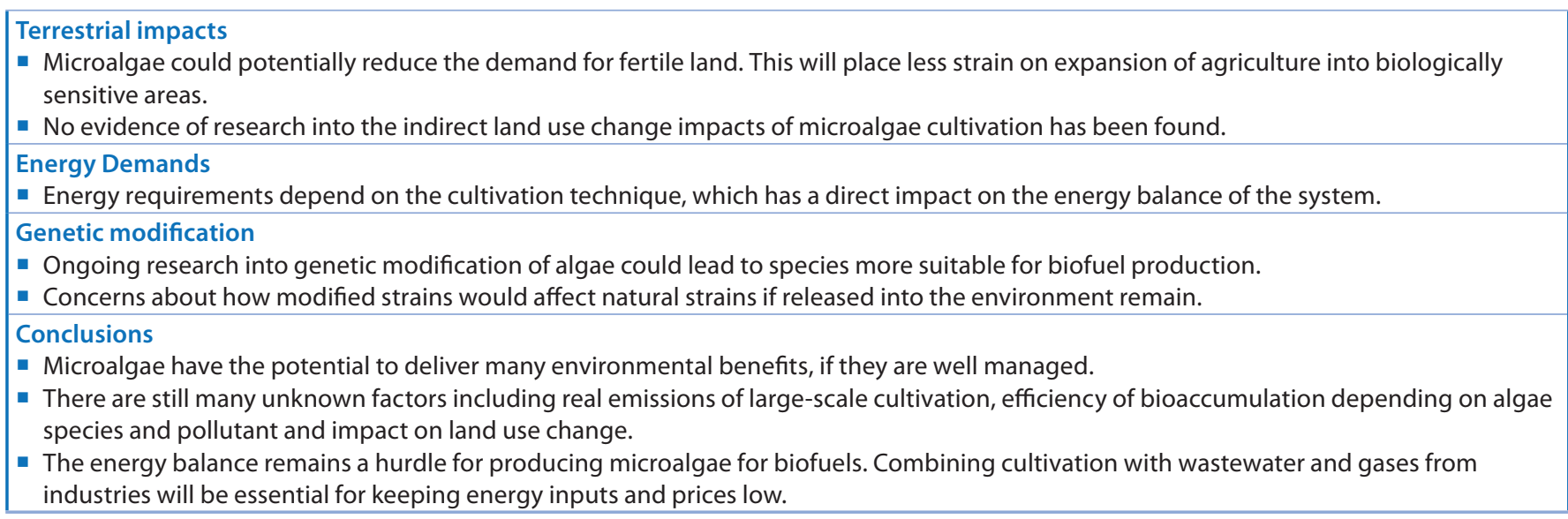

\section{References}

$1 \quad{ }^{* *}$ Mata TM, Martins AA, Caetano NS. Microalgae for biodiesel production and other applications: a review. Renew. Sustain. Energy Rev. [Internet] 14(1), 217-232 (2010). Available from: http://linkinghub.elsevier. com/retrieve/pii/S1364032109001646.

- **Detailed introduction to industrial applications of microalgae

2 Dragone, G., Fernandes, B., Vicente, A.A. and Teixeira, J.A. Third generation biofuels from microalgae. In: Mendez-Vilas A. (ed.), Current Research, Technology and Education Topics in Applied Microbiology and Microbial Biotechnology, 1355-1366, Formatex Research Center, Spain. (2010).

3 Fagerstone KD, Quinn JC, Bradley TH, De Long SK, Marchese AJ. Quantitative measurement of direct nitrous oxide emissions from microalgae cultivation. Environ. Sci. Technol. 45(21), 9449-9456 (2011).

4 Ferrón S, Ho DT, Johnson ZI, Huntley ME. Air-water fluxes of $\mathrm{N}_{2} \mathrm{O}$ and $\mathrm{CH}_{4}$ during microalgae (Staurosira sp.) cultivation in an open raceway pond. Environ. Sci. Technol. [Internet] 46(19), 10842-10848 (2012). Available from: http://www.ncbi.nlm.nih. gov/pubmed/22920714.

5 Yang J, Xu M, Zhang X, Hu Q, Sommerfeld M, Chen Y. Life-cycle analysis on biodiesel production from microalgae: water footprint and nutrients balance. Bioresour. Technol. 102(1), 159-165 (2011).

6 Batan L, Quinn JC, Bradley TH. Analysis of water footprint of a photobioreactor microalgae biofuel production system from blue, green and lifecycle perspectives. Algal Res. (2013).

7 Guieysse B, Béchet Q, Shilton A. Variability and uncertainty in water demand and water footprint assessments of fresh algae cultivation based on case studies from five climatic regions. Bioresour. Technol. 128, 317-323 (2013).

$8{ }^{*}$ Christenson L, Sims R. Production and harvesting of microalgae for wastewater treatment, biofuels, and bioproducts. Biotechnol. Adv. 29(6), 686-702 (2011).

- * Review of the potential uses for microalgae and options for harvesting

9 Abdel-Raouf N, Al-Homaidan AA, Ibraheem IBM. Microalgae and wastewater treatment. Saudi J. Biol. Sci. [Internet] 19(3), 257-275 (2012). Available from: http://linkinghub. elsevier.com/retrieve/pii/S1319562X 12000332.

10 Li Y, Chen Y-F, Chen P, et al. Characterization of a microalga Chlorella sp. well adapted to highly concentrated municipal wastewater for nutrient removal and biodiesel production. Bioresour. Technol. 102(8), 5138-5144 (2011).

11 Woo S-G, Yoo K, Lee J, et al. Comparison of fatty acid analysis methods for assessing biorefinery applicability of wastewater cultivated microalgae. Talanta [Internet] 1-8 (2012). Available from: http://linkinghub. elsevier.com/retrieve/pii/ S0039914012002974.

12 Smith VH, Sturm BSM, Denoyelles FJ, Billings $S$ a. The ecology of algal biodiesel production. Trends Ecol. Evol. [Internet] 25(5), 301-309 (2010). Available from: http://www.ncbi.nlm.nih.gov/pubmed/ 20022660.

13 Council NR. Environmental Effects. In: Sustainable Development of Algal Biofuels in the United States. The National Academies Press, Washington, DC, 139-190 (2012).

- $\quad * *$ Overview of many potential impacts of microalgae cultivation and opportunities for mitigation
14 Council of the European Parliment. Directive 2009/28/EC on the promotion of the use of energy from renewable sources. European Union.

15 Department for Transport. The Renewable Transport Fuel Obligations (Amendment). Sustainable and Renewable Fuels. Department for Transport, UK (2013).

16 Lane I. Brazil's government announces rise in ethanol blending to 25\% [Internet] Biofuels Dig. (2013). Available from: http://www. biofuelsdigest.com/bdigest/2013/03/04/ brazils-government-announces-rise-inethanol-blending-to-25/.

17 Ministerio de Minas e Energia. Objectivos e Diretrizes [Internet] Biodiesel - Programa Nac. Prod. e Uso Biodiesel. Available from: http://www.mme.gov.br/programas/ biodiesel/menu/programa/objetivos_ diretrizes.html.

18 US EPA. Renewable Fuel Standard (RFS) [Internet] Fuels Fuel Addit. (2011). Available from: http://www.epa.gov/otaq/fuels/ renewablefuels/index.htm.

19 IEA. Energy Technology Perspectives: Scenarios and Stratergies to 2050. France: Paris.

20 Taiwan becomes top producer of algae medicine [Internet] Want China Times. (2012). Available from: http://www. wantchinatimes.com/news-subclass-cnt.aspx? $\mathrm{d}=20121228000001 \&$ cid $=1104$.

21 Thurmond W. Global Biofuels, Drop-In Fuels, Biochems Markets and Forecasts. In: Algae 2020 Volume 2. Emerging Markets Online, Houston, 1-4 (2011).

22 Borowitzka MA. A mass culture of dunaliella salina [Internet] Tech. Resour. Pap. , 180 (1990). Available from: http:// www.fao.org/docrep/field/003/ab728e/ ab728e06.htm. 
23 Feinberg DA. Fuel options from microalgae with representative chemical compositions [Internet] Colorado. Available from: http:// www.nrel.gov/docs/legosti/old/2427.pdf.

24 Olguín EJ. Dual purpose microalgae-bacteriabased systems that treat wastewater and produce biodiesel and chemical products within a Biorefinery. Biotechnol. Adv. [Internet] 30(5), 1031-1046 (2012). Available from: http:/www.ncbi.nlm.nih.gov/ pubmed/22609182.

25 US Department for Energy. National Algal Biofuels Technology Roadmap [Internet]. Maryland Available from: http://biomass. energy.gov.

26 Miao X, Wu Q. Biodiesel production from heterotrophic microalgal oil. Bioresour. Technol. [Internet] 97(6), 841-846 (2006). Available from: http://www.ncbi.nlm.nih.gov/ pubmed/15936938.

27 Biller P, Ross AB. Potential yields and properties of oil from the hydrothermal liquefaction of microalgae with differen biochemical content. Bioresour. Technol. 102(1), 215-225 (2011)

28 Thomas G. Overview of Storage Development. In: US DOE Hydrogen Programme 2000 Annual Review. California (2000).

29 Pradhan A, Shrestha DS, Mcaloon A, Yee W, Haas M, Duffield JA. Energy life-cycle assessment of soybean biodiesel revisited. Am. Soc. Agric. Biol. Eng. 54(3), 1031-1039 (2011).

30 Lyons PE, Plisga B. Standard Handbook of Petroleum and Natural Gas Engineering. 2nd ed. Gulf Professional Publishing, Burlington.

31 Dufreche S, Hernandez R, French T, Sparks D, Zappi M, Alley E. Extraction of lipids from municipal wastewater plant microorganisms for production of biodiesel. $J$. Am. Oil Chem. Soc. [Internet] 84(2), 181-187 (2007). Available from: http://www. springerlink.com/index/10.1007/s11746-0061022-4.

32 May PI. Use of an Algal Turf Scrubber to Reduce Nutrient Loadings and Produce Biofuel at a Wastewater Treatment Plant on Jamaica Bay, New York City. In: 5th National Conference on Coastal and Estuarine Habitat Restoration. Restore America's Estuaries, Texas (2010).

33 Li Y, Zhou W, Hu B, Min M, Chen P, Ruan RR. Integration of algae cultivation as biodiesel production feedstock with municipal wastewater treatment: strains screening and significance evaluation of environmental factors. Bioresour. Technol. 102(23), 10861-10867 (2011).

34 Ramachandra TV, Durga Madhab M, Shilpi S, Joshi NV. Algal biofuel from urban wastewater in India: Scope and challenges.
Renew. Sustain. Energy Rev. [Internet] 21, 767-777 (2013). Available from: http:// linkinghub.elsevier.com/retrieve/pii/ S1364032112007320.

35 Wu LF, Chen PC, Huang AP, Lee CM. The feasibility of biodiesel production by microalgae using industrial wastewater. Bioresour. Technol. 113, 14-18 (2012).

36 UN-Water. World Water Development Report (WWDR4): Managing Water under Uncertainty and Risk. Paris.

37 Water UK. Wastewater Treatment and Recycling [Internet]. London. Available from: http://www.water.org.uk/home/news/ press-releases/wastewater-pamphlet.

38 Sheehan J. A Look Back at the U.S Department of Energy's Aquatic Species Program: Biodiesel from Algae. Colorado.

39 Chen YH, Walker TH. Biomass and lipid production of heterotrophic microalgae Chlorella protothecoides by using biodieselderived crude glycerol. Biotechnol. Lett. 33(10), 1973-1983 (2011).

40 Wells SG, Gertler AW. Algal-Based Fuels., Reno, Nevada.

41 Lardon L, Hélias A, Sialve B, Steyer J-P, Bernard O. Life-cycle assessment of biodiesel production from microalgae. Environ. Sci. Technol. 43(17), 6475-6481 (2009).

42 Correll DL. The role of phosphorus in the eutrophication of receiving waters: a review. $J$. Environ. Qual. [Internet] 27(2), 261 (1998). Available from: https://www.agronomy.org/ publications/jeq/abstracts/27/2/ JEQ0270020261.

43 Crouzet P. Nutrients in European ecosystems In: Nutrients in European Ecosystems. Thyssen TJ (Ed.). European Environmental Agency, Office for Official Publications of the European Communities, Luxembourg, 145-153 (1999).

$44{ }^{* *}$ Science Communication Unit. Sustainable Phosphorus Use [Internet]. Bristol. Available from: http://ec.europa.eu/scienceenvironment-policy.

45 Cordell D, Drangert J-O, White S. The story of phosphorus: Global food security and food for thought. Glob. Environ. Chang. 19(2), 292-305 (2009).

46 Cordell D, Rosemarin A, Schröder JJ, Smit a L. Towards global phosphorus security: a systems framework for phosphorus recovery and reuse options. Chemosphere. 84(6), 747-758 (2011).

47 Linderholm K, Tillman A-M, Mattsson JE. Life cycle assessment of phosphorus alternatives for Swedish agriculture. Resour. Conserv. Recycl. 66, 27-39 (2012).
48 Shilton AN, Mara DD, Craggs R, Powell N. Solar-powered aeration and disinfection, anaerobic co-digestion, biological $\mathrm{CO}_{2}$ scrubbing and biofuel production: the energy and carbon management opportunities of waste stabilization ponds. Water Sci. Technol. 58(1), 253-258 (2008).

49 Mara DD. Domestic Wastewater Treatment in Developing Countries. Earthscan, London (2004).

50 Camargo Valero MA, Mara DD, Newton RJ Nitrogen removal in maturation waste stabilisation ponds via biological uptake and sedimentation of dead biomass. Water Sci. Technol. 61, 1027-1034 (2010).

51 Heredia-Arroyo T, Wei W, Hu B. Oil accumulation via heterotrophic/mixotrophic chlorella protothecoides. Appl. Biochem. Biotechnol. 162(7), 1978-1995 (2010).

52 Kathy E. Lee, Larry B. Barber, Edward T. Furlong, et al. Antibiotics Field Data-Scientific Investigations Report 2004-5138 [Internet]. Minnesota Available from: http://pubs.usgs. gov/sir/2004/5138/antibiotics.html (2004).

53 Martín J, Camacho-Muñoz D, Santos JL, Aparicio I, Alonso E. Occurrence of pharmaceutical compounds in wastewater and sludge from wastewater treatment plants: removal and ecotoxicological impact of wastewater discharges and sludge disposal. $J$. Hazard. Mater. [Internet] 239-240, 40-47 (2012). Available from: http://www.ncbi.nlm. nih.gov/pubmed/22608399.

54 Subashchandrabose SR, Ramakrishnan B, Megharaj M, Venkateswarlu K, Naidu R. Mixotrophic cyanobacteria and microalgae as distinctive biological agents for organic pollutant degradation. Environ. Int. [Internet] 51, 59-72 (2013). Available from: http://www.ncbi.nlm.nih.gov/ pubmed/23201778.

55 Kumar A, Ergas S, Yuan X, et al. Enhanced $\mathrm{CO}(2)$ fixation and biofuel production via microalgae: recent developments and future directions. Trends Biotechnol. [Internet] 28(7), 371-80 (2010). Available from: http://www. ncbi.nlm.nih.gov/pubmed/20541270.

56 Butler GL, Deason TR, O'Kelley JC. Loss of five pesticides from cultures of twenty-one planktonic algae. Bull. Environ. Contam. Toxicol. [Internet] 13(2), 149-152 (1975). Available from: http://www.ncbi.nlm.nih.gov/ pubmed/1125439.

57 Khoshmanesh A, Lawson F, Prince IG. Cell surface area as a major parameter in the uptake of cadmium by unicellular green microalgae. Chem. Eng. J. 65, 13-19 (1997).

58 Perron M-C, Juneau P. Effect of endocrine disrupters on photosystem II energy fluxes of 
green algae and cyanobacteria. Environ. Res 111, 520-529 (2011).

59 EPA. Drinking water contaminants [Internet]. Natl. Prim. Drink. Water Regul. (2013). Available from: http://water.epa.gov/ drink/contaminants/.

60 US EPA. Nutrient pollution [Internet]. (2013). Available from: http://www2.epa. gov/nutrientpollution/problem.

61 Food Standards Agency. Risk assessment: phosphorus [Internet]. In: Expert Group on Vitamins and Minerals. Risk assessment: Phosphorus [Internet]. Food Standards Agency Available from: http://multimedia.food.gov.uk/ multimedia/pdfs/evm_phosphorous.pdf (2003).

62 National Institute of Environmental Health Endocrine disruptors [Internet]. (May) (2013). Available from: http://www.niehs. nih.gov/health/materials/endocrine_ disruptors_508.pdf.

63 US EPA. National Recommended Water Quality Criteria [Internet]. (2013). Available from: http://water.epa.gov/scitech/ swguidance/standards/criteria/current/index. cfm\#U.

64 WHO Guidelines. Polynuclear aromatic hydrocarbons in drinking-water. In: Guidelines for Drinking-water Quality: Health Criteria and Other Supporting Information. Geneva (1998)

65 Howe G, Merchant S. Heavy metal-activated synthesis of peptides in chlamydomonas reinhardtii. Plant Physiol. [Internet] 98(1), 127-136 (1992). Available from: http://www. pubmedcentral.nih.gov/articlerender.fcgi?artid=1 080159\& tool $=$ pmcentrez $\&$ rendertype $=$ abstract.

66 Fuhrman JA, Suttle CA. Viruses in marine planktonic systems. Oceanography 6(2) (1993).

67 Beltrami E, Carroll TO. Modeling the role of viral disease in recurrent phytoplankton blooms. J. Math. Biol. 32, 857-863 (1994).

68 Bergh O, Borsheim K, Bratbak G, Heldal M. High abundance of viruses found in aquatic environments. Nature 340, 467-468 (1989).

69 Curtis TP, Mara DD, Silva SA. The effect of sunlight on faecal coliforms in ponds: implications for research and design. Water Sci. Technol. 26(7-8), 1729-1738 (1992).

70 Letcher PM, Lopez S, Schmieder R, et al. Characterization of Amoeboaphelidium protococcarum, an algal parasite new to the cryptomycota isolated from an outdoor algal pond used for the production of biofuel. PLoS One [Internet]. 8(2), e56232 (2013). Available from: http://www.pubmedcentral. nih.gov/articlerender.fcgi?artid=3577820\&to $\mathrm{ol}=$ pmcentrez\&rendertype $=$ abstract.
71 Water Footprint Network. Water footprint and virtual water [Internet]. (2013). Available from: http://www.waterfootprint. org/?page=files $/$ Water-energy.

72 Wigmosta M, Coleman A, Skaggs R, Huesemann M, Lane L. National microalgae biofuel production potential and resource demand. Water Resour. Res. 47(3), 1-13 (2011).

73 US EIA. Petroleum basic statistics [Internet]. Available from: www.eia.gov/basics/quickoil. html.

74 *Harmelen T van, Oonk H. Microalgae Biofixation Processes: Applications and Potential Contributions to Greenhouse Gas Mitigation Options. Apeldoorn.

- *Interesting study of suitable locations for microalgae cultivation

75 Venteris ER, Skaggs RL, Coleman AM, Wigmosta MS. A GIS cost model to assess the availability of freshwater, seawater, and saline groundwater for algal biofuel production in the United States. Environ. Sci. Technol. 47(9), 4840-4849 (2013).

76 European Commission. New Commission proposal to minimise the climate impacts of biofuel production. Press Rele(October) (2012).

77 Submariner. Algae production in offshore wind parks [Internet]. Reg. Act. (2011). Available from: http://www.submarinerproject.eu/index.php?option=com_content $\&$ view=article \&id=159:algae-production-inoffshore-wind-parks\&catid=62: regionalactivi tiesdenmark \&Itemid=373.

78 Doan TTY, Sivaloganathan B, Obbard JP. Screening of marine microalgae for biodiesel feedstock. Biomass Bioenerg. [Internet] 35(7), 2534-2544 (2011). Available from: http:// linkinghub.elsevier.com/retrieve/pii/ S0961953411000961.

79 Carlsson AS, van Beilen JB, Möller R, Clayton D. Micro- and macro-algae: utility for industrial applications. 1st ed. CPL Press, Newbury.

80 ARUP. Havant Thicket Winter Storage Reservoir Environmental Impact Assessment Scoping Report [Internet]. Havant, UK Available from: http://www.portsmouthwater. co.uk/uploadedFiles/HTWSR/News/EIA_ Scoping_022009.pdf.

81 Francisco ÉC, Neves DB, Jacob-Lopes E, Franco TT. Microalgae as feedstock for biodiesel production: carbon dioxide sequestration, lipid production and biofuel quality. J. Chem. Technol. Biotechnol. [Internet] 85(3), 395-403 (2010). Available from: http://doi.wiley.com/10.1002/ jctb. 2338 .
82 Bilanovic D, Andargatchew A, Kroeger T, Shelef G. Freshwater and marine microalgae sequestering of $\mathrm{CO} 2$ at different $\mathrm{C}$ and $\mathrm{N}$ concentrations - response surface methodology analysis. Energy Convers. Manag. [Internet] 50(2), 262-267 (2009). Available from: http://linkinghub.elsevier com/retrieve/pii/S0196890408003725.

83 Rosenberg JN, Mathias A, Korth K, Betenbaugh MJ, Oyler G a. Microalgal biomass production and carbon dioxide sequestration from an integrated ethanol biorefinery in Iowa: a technical appraisal and economic feasibility evaluation. Biomass Bioenerg. [Internet] 35(9), 3865-3876 (2011). Available from: http://linkinghub.elsevier. com/retrieve/pii/S096195341100287X.

84 Frank ED, Han J, Palou-Rivera I, Elgowainy A., Wang MQ. Methane and nitrous oxide emissions affect the life-cycle analysis of algal biofuels. Environ. Res. Lett. 7(1), 014030 (2012).

85 Karl DM, Beversdorf L, Björkman KM, Church MJ, Martinez A, Delong EF. Aerobic production of methane in the sea. Nat. Geosci [Internet] 1(7), 473-478 (2008). Available from: http://www.nature.com/doifinder/ 10.1038/ngeo234.

86 IPCC. Working group I contribution to the IPCC fifth assessment report, Climate change 2013: the physical science basis.

87 Keppler F, Hamilton JTG, Brass M, Röckmann T. Methane emissions from terrestrial plants under aerobic conditions. Nature [Internet] 439(7073), 187-91 (2006). Available from: http://www.ncbi.nlm.nih.gov/ pubmed/16407949.

88 Ferrón S, Ho DT, Johnson ZI, Huntley ME. Air-water fluxes of $\mathrm{N}_{2} \mathrm{O}$ and $\mathrm{CH}_{4}$ during microalgae (Staurosira sp.) cultivation in an open raceway pond. Environ. Sci. Technol. [Internet] 46(19), 10842-10848 (2012). Available from: http://www.ncbi.nlm.nih. gov/pubmed/22920714.

89 Poth M, Focht DD. N Kinetic Analysis of N(2) O Production by nitrosomonas europaea: an examination of nitrifier denitrification. Appl. Environ. Microbiol. [Internet] 49(5), 1134-41 (1985). Available from: http://www. pubmedcentral.nih.gov/articlerender.fcgi?artid= 238519\& tool=pmcentrez\&rendertype=abstract.

90 Mampaey KE, Beuckels B, Kampschreur MJ, Kleerebezem R, van Loosdrecht MCM, Volcke EIP. Modelling nitrous and nitric oxide emissions by autotrophic ammoniaoxidizing bacteria. Environ. Technol. [Internet] 34(12), 1555-1566 (2013). Available from: http://www.tandfonline.com/ doi/abs/10.1080/09593330.2012.758666. 
91 Sengupta S, Ergas SJ. Autotrophic Biological Denitrification with Elemental Sulfur or Hydrogen for Complete Removal of NitrateNitrogen from a Septic System Wastewater. Massachusetts (2006).

92 Camargo Valero M, Read L, Mara D, Newton R, Curtis T, Davenport R. Nitrificationdenitrification in waste stabilisation ponds: a mechanism for permanent nitrogen removal in maturation ponds. Water Sci. Technol. 61, 1137-1146 (2010).

93 Guieysse B, Plouviez M, Coilhac M, Cazali L. Nitrous oxide $\left(\mathrm{N}_{2} \mathrm{O}\right)$ production in axenic Chlorella vulgaris microalgae cultures: evidence, putative pathways, and potential environmental impacts. Biogeosciences 10, 6737-6746 (2013).

94 Cohen Y, Gordon LI. Nitrous oxide in the oxygen minimum of the eastern tropical North Pacific: evidence for its consumption during denitrification and possible mechanisms for its production. Deep. Res. 25, 509-524 (1978).

95 Weathers PJ. N20 Evolution by green algae. Appl. Environ. Microbiol. 48(6), 1251-1253 (1984).

96 Mulbry W, Westhead EK, Pizarro C, Sikora L. Recycling of manure nutrients: use of algal biomass from dairy manure treatment as a slow release fertilizer. Bioresour. Technol. [Internet] 96(4), 451-8 (2005). Available from: http://www.ncbi.nlm.nih.gov/ pubmed/15491826.

97 Young AM. Zeolite - based algae biofilm rotating photobioreactor for algae and biomass production [Internet] All Grad. Theses Diss. 986 (2011). Available from: http://digitalcommons.usu.edu/etd/986.

98 Bowmer KH. Inhibition of algal photosynthesis to control $\mathrm{pH}$ and reduce ammonia volatilization from rice floodwater. 29(April 1986), 13-29 (1987).

99 De Assunção FA, von Sperling M. Importance of the ammonia volatilization rates in shallow maturation ponds treating UASB reactor effluent. Water Sci. Technol. 66(6), 12391246 (2012).

100 Camargo-Valero MA. Nitrogen transformation pathways and removal mechanisms in domestic wastewater treatment by maturation ponds. PhD thesis, School of Civil Engineering, University of Leeds (2008). Available from http://www.personal.leeds.ac. uk/-cen6ddm/ThesisMiller.html.

101 Camargo Valero (MA.), Mara DD. Nitrogen removal via ammonia volatilization in maturation ponds. Water Sci. Technol.
[Internet] 55(11), 87 (2007). Available from: http://www.iwaponline.com/wst/05511/ wst055110087.htm.

102 Camargo Valero M a, Mara DD. Ammonia volatilisation in waste stabilisation ponds: a cascade of misinterpretations? Water Sci. Technol. [Internet] 61(3), 555-561 (2010). Available from: http://www.ncbi.nlm.nih. gov/pubmed/20150690.

103 Cussler EL. Diffusion: Mass Transfer in Fluid Systems. 2nd ed. Cambridge University Press, New York.

104 Thorenz UR, Kundel M, Huang R, Hoffmann T. Trace analysis of short-lived iodine-containing volatiles emitted by different types of algae. In: European Geosciences Union General Assembly. NASA, Vienna, 202527 (2012).

105 Colomb A, Yassaa N, Williams J, Peeken I, Lochte K. Screening volatile organic compounds (VOCs) emissions from five marine phytoplankton species by head space gas chromatography/mass spectrometry (HS-GC/MS). J. Environ. Monit. [Internet] 10(3), 325-30 (2008). Available from: http:// www.ncbi.nlm.nih.gov/pubmed/18392274.

106 Carpenter LJ, Malin G, Liss PS. Novel biogenic iodine-containing trihalomethanes and other short-lived halocarbons in the coastal east Atlantic. Global Biogeochem. Cycles. 14(4), 1191-1204 (2000).

107 Ballschmiter K. Pattern and sources of naturally produced organohalogens in the marine environment: biogenic formation of organohalogens. Chemosphere [Internet] 52(2), 313-324 (2003). Available from: http://www. ncbi.nlm.nih.gov/pubmed/12738255.

108 Ko MKW, Poulet G, Blake DR, et al. Very short-lived halogen and sulfur substances Report No. 47. In: Scientific Assessment of Ozone Depletion: 2002 Global Ozone Research and Monitoring Project. Geneva (2003).

109 Law KS, Sturges WT, Blake DR, et al. Halogenated very short-lived substances Report No. 50. In: Scientific Assessment of Ozone Depletion: 2006 Global Ozone Research and Monitoring Project. Geneva (2006).

110 McFiggans G, Coe H, Burgess R, et al. Direct evidence for coastal iodine particles from Laminaria macroalgae - linkage to emissions of molecular iodine. Atmos. Chem. Phys. Discuss. 4, 939-967 (2004).

111 O'Dowd CD, Jimenez JL, Baherini R, et al. Marine aerosol formation from biogenic iodine emissions. Nature 417(June) (2002).

112 Yoch DC. Dimethylsulfoniopropionate: It's sources, role in the marine food web and biological degradation to dimethylsulfide. Appl. Environ. Microbiol. 68(12), 5804-5815 (2002).

113 Charlson RJ, Lovelock JE, Andreae MO, Warren SG. Oceanic phytoplankton, atmospheric sulphur, cloud albedo and climate. Nature 326, 655-661 (1987).

114 Matos CT, Gouveia L, Morais ARC, Reis A, Bogel-Lukasik RM. Green metrics evaluation of isoprene production by microalgae and bacteria. Green Chem. [Internet] (2013). Available from: http://pubs.rsc.org/en/Content/ ArticleLanding/ 2013/GC/c3gc40997j.

115 Kesselmeier J, Staudt M. Biogenic Volatile organic compounds (VOC): an overview on emission, physiology and ecology. J. Atmos. Chem. 23-88 (1999).

116 Stone D, Evans MJ, Edwards PM, et al. Isoprene oxidation mechanisms: measurements and modelling of $\mathrm{OH}$ and $\mathrm{HO}_{2}$ over a South-East Asian tropical rainforest during the OP3 field campaign. Atmos. Chem. Phys. [Internet] 11(13), 6749-6771 (2011). Available from: http:// www.atmos-chem-phys.net/11/6749/2011/.

117 Sanderson MG. Effect of climate change on isoprene emissions and surface ozone levels. Geophys. Res. Lett. [Internet] 30(18), 1936 (2003). Available from: http://doi.wiley. com/10.1029/2003GL017642.

118 Carlton AG, Wiedinmyer C, Kroll JH. A review of secondary organic aerosol (SOA) formation from isoprene. Atmos. Chem. Phys. Discuss. [Internet] 9(2), 8261-8305 (2009). Available from: http://www.atmos-chemphys-discuss.net/9/8261/2009/.

119 Tai APK, Mickley LJ, Heald CL, Wu S. Effect of $\mathrm{CO}_{2}$ inhibition on biogenic isoprene emission: implications for air quality under 2000 to 2050 changes in climate, vegetation, and land use. Geophys. Res. Lett. [Internet] 40(13), 3479-3483 (2013). Available from: http://doi.wiley.com/10.1002/grl.50650.

120 Ferreira J, Reeves CE, Murphy JG, GarciaCarreras L, Parker DJ, Oram DE. Isoprene emissions modelling for West Africa: MEGAN model evaluation and sensitivity analysis. Atmos. Chem. Phys. [Internet] 10(17), 8453-8467 (2010). Available from: http:// www.atmos-chem-phys.net/10/8453/2010/.

121 Potter CS, Alexander SE, Coughlan JC, Klooster $S$ a. Modeling biogenic emissions of isoprene: exploration of model drivers, climate control algorithms, and use of global satellite observations. Atmos. Environ. [Internet] 35(35), 6151-6165 (2001). Available from: http://linkinghub.elsevier.com/retrieve/pii/ S1352231001003909. 
122 Monson RK, Holland EA. Biospheric trace gas fluxes and their control over tropospheric chemistry. Annu. Rev. Ecol. Syst. 32, 547-576 (2001).

123 O’Dowd CD, Jimenez JL, Bahreini $\mathrm{R}$, et al. Marine aerosol formation from biogenic iodine emissions. Nature 417(6889), 632-636 (2002).

124 Ashworth DJ, Luo L, Yates SR. Pesticide emissions from soil - fate and predictability. Outlook Pest Manag. 4(1), 4-7 (2013).

125 Beatriz Hernández-Carlos MMG-A. Metabolites from freshwater aquatic microalgae and fungi as potential natural pesticides. Phytochem. Rev. 10(2), 261-286 (2011).

126 EEA. Environmental impacts: ozone and health. [Internet] (2004). Available from: http://www.eea.europa.eu/maps/ozone/ impacts/bad-for-agriculture.

127 Morais MG, Radmann EM, A. CJ. Biofixation of $\mathrm{CO}_{2}$ from synthetic combustion gas using cultivated microalgae in three-stage serial tubular photobioreactors. $J$. Biosci. 66(5-6), 313-318 (2011).

128 Chen G, Davis D, Kasibhatla P, Bandy A, Thornton D, Blake D. A mass-balance/ photochemical assessment of DMS sea-to-air flux as inferred from NASA GTE PEW-West $A$ and B observations. J. Geophys. Res. 104(D5), 5471-5482 (1999).

129 Renard JJ, Calidonna SE, Henley MV. Fate of ammonia in the atmosphere - a review for applicability to hazardous releases. J. Hazard. Mater. [Internet] 108(1-2), 29-60 (2004). Available from: http://www.ncbi.nlm.nih. gov/pubmed/15081162.

130 Ballschmiter K. Pattern and sources of naturally produced organohalogens in the marine environment: biogenic formation of organohalogens. Chemosphere 52(2), 313-324 (2003).

131 Kamilli K, Ofner J, Zetzsch C, Held A. Formation of halogen-induced secondary organic aerosol (XOA) 15, 14214 (2013).

$132{ }^{* *}$ Handler RM, Canter CE, Kalnes TN, et al. Evaluation of environmental impacts from microalgae cultivation in open-air raceway ponds: analysis of the prior literature and investigation of wide variance in predicted impacts. Algal Res. [Internet] 1(1), 83-92 (2012). Available from: http://linkinghub. elsevier.com/retrieve/pii/ S2211926412000069.

- ${ }^{* *}$ Quantitative analysis of the potential GHG emissions, fossil energy demand, and consumptive freshwater use for microalgae cultivation

133 Campbell PK, Beer T, Batten D. Life cycle assessment of biodiesel production from microalgae in ponds. Bioresour. Technol. [Internet] 102(1), 50-56 (2011). Available from: http://www.ncbi.nlm.nih.gov/pubmed/ 20594828.

134 Clarens AF, Resurreccion EP, White M a, Colosi LM. Environmental life cycle comparison of algae to other bioenergy feedstocks. Environ. Sci. Technol. [Internet] 44(5), 1813-1819 (2010). Available from: http://www.ncbi.nlm.nih.gov/ pubmed/20085253.

135 Lardon L, Hélias A, Sialve B, Steyer J-P, Bernard O. Life-Cycle assessment of biodiesel production from microalgae. Environ. Sci. Technol. 43(17), 6475-6481 (2009).

136 Jorquera O, Kiperstok A, Sales E a, Embiruçu M, Ghirardi ML. Comparative energy life-cycle analyses of microalgal biomass production in open ponds and photobioreactors. Bioresour. Technol. 101(4), 1406-1413 (2010).

137 Razon LF, Tan RR. Net energy analysis of the production of biodiesel and biogas from the microalgae: Haematococcus pluvialis and Nannochloropsis. Appl. Energy. 88(10), 3507-3514 (2011).

138 Khoo HH, Sharratt PN, Das P, Balasubramanian RK, Naraharisetti PK, Shaik S. Life cycle energy and CO2 analysis of microalgae-to-biodiesel: preliminary results and comparisons. Bioresour. Technol. 102(10), 5800-5807 (2011).

139 Stephenson AL, Kazamia E, Dennis JS, Howe CJ, Scott $S$ a., Smith AG. Life-cycle assessment of potential algal biodiesel production in the United Kingdom: a comparison of raceways and air-lift tubular bioreactors. Energ. Fuels [Internet] 24(7), 4062-4077 (2010). Available from: http:// pubs.acs.org/doi/abs/10.1021/ef1003123.

140 Plappally a. K, Lienhard V JH. Energy requirements for water production, treatment, end use, reclamation, and disposal. Renew. Sustain. Energ. Rev. 16(7), 4818-4848 (2012)

141 Ozkan A, Kinney K, Katz L, Berberoglu H. Reduction of water and energy requirement of algae cultivation using an algae biofilm photobioreactor. Bioresour. Technol. [Internet] 114, 542-8 (2012). Available from: http:// www.ncbi.nlm.nih.gov/pubmed/22503193.

142 Johnson MB, Wen Z. Development of an attached microalgal growth system for biofuel production. Appl. Microbiol. Biotechnol. 85(3), 525-534 (2010).

143 Gao C, Zhai Y, Ding Y, Wu Q. Application of sweet sorghum for biodiesel production by heterotrophic microalga Chlorella protothecoides. Appl. Energy [Internet] 87(3), 756-761 (2010). Available from: http:// linkinghub.elsevier.com/retrieve/pii/ S0306261909003857.

144 Li P, Miao X, Li R, Zhong J. In situ biodiesel production from fast-growing and high oil content Chlorella pyrenoidosa in rice straw hydrolysate. J. Biomed. Biotechnol. [Internet] 2011, 141207 (2011). Available from: http:// www.pubmedcentral.nih.gov/articlerender.fcg i artid=3026997\&tool=pmcentrez\&renderty pe $=$ abstract.

145 Lohrey C, Kochergin V. Biodiesel production from microalgae: co-location with sugar mills. Bioresour. Technol. [Internet] 108, 76-82 (2012). Available from: http://www.ncbi.nlm.nih.gov/ pubmed/ 22265980.

146 Hou J, Zhang P, Yuan X, Zheng Y. Life cycle assessment of biodiesel from soybean, jatropha and microalgae in China conditions. Renew. Sustain. Energy Rev. [Internet] 15(9), 5081-5091 (2011). Available from: http:// linkinghub.elsevier.com/retrieve/pii/ S1364032111002899. 